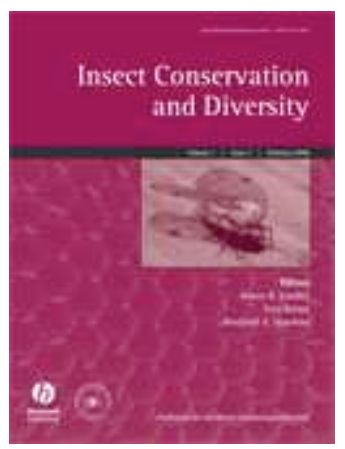

\title{
The role of grassland sward islets in the distribution of arthropods in cattle pastures.
}

\begin{tabular}{|c|c|}
\hline Journal: & Insect Conservation and Diversity \\
\hline Manuscript ID: & ICDIV-09-0118.R2 \\
\hline Manuscript Type: & Original Article \\
\hline $\begin{array}{r}\text { Date Submitted by the } \\
\text { Author: }\end{array}$ & $\mathrm{n} / \mathrm{a}$ \\
\hline Complete List of Authors: & $\begin{array}{l}\text { Helden, Alvin; Anglia Ruskin University, Animal and Environmental } \\
\text { Research Group, Department of Life Sciences; University College } \\
\text { Dublin, UCD School of Agriculture, Food Science and Veterinary } \\
\text { Medicine } \\
\text { Anderson, Annette; University College Dublin, UCD School of } \\
\text { Agriculture, Food Science and Veterinary Medicine } \\
\text { Sheridan, Helen; University College Dublin, UCD School of } \\
\text { Agriculture, Food Science and Veterinary Medicine } \\
\text { Purvis, Gordon; University College Dublin, UCD School of } \\
\text { Agriculture, Food Science and Veterinary Medicine }\end{array}$ \\
\hline Keywords: & $\begin{array}{l}\text { insects, spiders, biodiversity, agriculture, grazing, refugia, spatial } \\
\text { heterogeneity }\end{array}$ \\
\hline
\end{tabular}

\section{s ScholarONE" \\ Manuscript Central}




\title{
The role of grassland sward islets in the distribution of arthropods in cattle pastures.
}

\author{
ALVIN J. HELDEN ${ }^{1,2}$, ANNETTE ANDERSON ${ }^{2}$ HELEN SHERIDAN $^{2} \&$ GORDON $^{2}$ \\ PURVIS $^{2}$ \\ ${ }^{1}$ Animal and Environmental Research Group, Department of Life Sciences, Anglia Ruskin \\ University, East Road, Cambridge, CB1 1PT, UK \\ ${ }^{2}$ UCD School of Agriculture, Food Science and Veterinary Medicine, University College \\ Dublin, Belfield, Dublin 4, Ireland
}

Address for correspondence: Dr Alvin Helden, Animal and Environmental Research Group, Department of Life Sciences, Anglia Ruskin University, East Road, Cambridge, CB1 1PT, UK. Tel: +44 1223363271 Fax: +44 1223417712 e-mail: a.helden@anglia.ac.uk

Running title: Arthropods and sward islets
Abstract
1. It is well documented that cattle reduce their grazing activity in the vicinity of cattle dung, which gives rise to distinct patches, or islets as they have been termed, of longer sward. The influence of such islets on pasture utilisation and agronomic performance has been widely studied, but very little information is available concerning their influence on grassland biodiversity. 
2. In this study the abundance and distribution of arthropods in relation to islets was assessed, using suction sampling, at 26 commercial farms and in a replicated pasture management experiment in the south and east of Ireland.

3. Islets were found to cover approximately $24 \%$ of pastures and to contain between 40 and $50 \%$ of arthropod individuals.

4. Islets consistently contained a higher density of arthropods, even when the difference in mean sward height between islets and more strongly grazed sward was accounted for. The relative concentration of arthropods in islets declined with increasing mean sward height, which may be related to a change in the recovery of well-grazed nonislet sward. Islets appear to act as refugia from sward removal.

5. The potential importance of islets in maintaining arthropod biodiversity within intensively grazed pastures and the wider landscape within intensive grass-based farming areas is discussed, particularly with reference to standard agronomic practices such as sward topping and chain harrowing, which aim to remove the sward heterogeneity created by grazing livestock.

Keywords. insects, spiders, biodiversity, agriculture, grazing, refugia, spatial heterogeneity 


\section{Introduction}

It has been known for many years that grazing by cattle is reduced, although not completely avoided, in the immediate vicinity of cattle dung (Marsh \& Campling, 1970; Norman \& Green, 1958). A number of studies have investigated the possible reasons behind the behaviour, including the smell of the dung and the coarseness, sugar content and nutrient content of the grass, but there have be no definitive answers (Bosker et al., 2002;

MacDiarmid \& Watkin, 1972; Marsh \& Campling, 1970; Marten \& Donker, 1964a, b; Plice, 1951). It may be that the dung causes an initial rejection in the proximal sward. With consequent differences in the chemical or physical characteristics the grazed and ungrazed vegetation maintaining the rejection by cattle (MacLusky, 1960; McNaughton, 1984; Norman $\&$ Green, 1958). Whatever the present reasons for such behaviour in grazing cattle, the underlying evolutionary explanation may lie in avoidance of infection by gastrointestinal parasite larvae, the distribution of which tends to remain highly concentrated in the vicinity of dung patches during the grazing season (Boom \& Sheath, 2008).

The result of this behaviour by cattle in relatively intensive grasslands, is that distinct patches of longer sward are typically found around dung patches (Figure 1) (MacDiarmid \& Watkin, 1972). These patches have been termed islets, due to the contrast between them and the more heavily grazed sward surrounding them, (Desender, 1982; Maelfait \& De Keer, 1990). Although islets have taller vegetation, the botanical composition is initially little changed from the remaining sward (MacDiarmid \& Watkin, 1971; Norman \& Green, 1958; Parish \& Turkington, 1990). However, some studies suggest that the spatial heterogeneity created by such patches, especially in soil nutrient status (Haynes \& Williams, 1993; Lantinga et al., 1987), is likely to influence relative plant population dynamics and the 
longer-term co-existence of sward species (Chesson, 2000; Schulte et al., 2003; Schwinning \& Parsons, 1996).

Islets have been estimated to cover between 10 and $47 \%$ of pasture area and to persist for between a few months to over a year, although both these characteristics vary with grazing intensity, rainfall and management such as cutting (Boswell, 1971; Castle \& MacDaid, 1972; Gibb et al., 1997; MacLusky, 1960; Marsh \& Campling, 1970; Marten \& Donker, 1964a; Norman \& Green, 1958; Tayler \& Large, 1955; Weeda, 1967). The extent and persistence of islets has often been considered to represent a reduction in productivity and consequently has stimulated many studies from an agronomic perspective (Bosker et al., 2002; Castle \& MacDaid, 1972; Greenhalgh \& Reid, 1968; MacLusky, 1960; Marsh \& Campling, 1970; Marten \& Donker, 1964a; Tayler \& Rudman, 1966). It is also a major reason for the practices of sward topping to reduce physical sward heterogeneity (and control weeds) and chain harrowing to re-distribute surface dung (Barry et al., 2002; Boswell, 1971; MacLusky, 1960; Norman \& Green, 1958; Weeda, 1967).

In contrast there has been little work done on the possible ecological effects of islets. Mikola (2009) recently reported a major study of the ecological effects of localised dungdeposition on plant and soil faunal communities in grazed pasture. Desender (1982), Desender et al. (1989) and D'Hulster and Desender $(1982,1984)$ found evidence that islets may be important overwintering sites for Carabidae and Staphylinidae, particularly as they are not trampled by cattle and cover a relatively large area. Some spiders (Araneae) are also thought to use islets for overwintering (De Keer et al., 1986; Desender et al., 1989; Maelfait \& De Keer, 1990). De Keer et al. (1989) found that the contrast in microhabitat conditions between the vegetation within and outside islets resulted in differences in the growing season distribution, abundance and behaviour of different spider species. The present authors are not 
aware of any other studies specifically focused on the distribution of above-ground arthropods relative to islets, although their value in maintaining heterogeneity and botanical diversity in grassland is well recognised (Chesson, 2000; Rook \& Tallowin, 2003; Wallis De Vries et al., 2007). Neither does there appear to have been any direct investigation in islets terms of above ground arthropod groups apart from Araneae, Carabidae and Staphylinidae.

There have been a number of studies of the arthropods found in more permanent tussock structures, including those in upland areas, in lowland field margins and in beetle banks. Unlike islets, these tussocks are associated with the growth form of specific grass or similar monocot plant species, such as the grasses Dactylis glomerata L. (Luff, 1965b), Nardus stricta L. (Dennis et al., 1998) and Holcus lanatus L. (Bossenbroek et al., 1977b). The importance of tussocks for arthropods, particularly in terms of overwintering, has long been recognised (Bayram \& Luff, 1993; Luff, 1965a; Luff, 1966; Pearce, 1948). It has been suggested that their value to arthropods is particularly associated with their sheltered microclimate, including reduced temperature and humidity fluctuation (Bossenbroek et al., 1977a, b; Luff, 1965b). At a larger habitat scale, the presence of tussocks helps to create heterogeneity within grasslands, which is considered a highly important factor in determining arthropod and other biodiversity (Benton et al., 2003; Dennis et al., 1998; Morris, 2000; Rook \& Tallowin, 2003; Woodcock et al., 2007). A reduction in structural diversity associated with intensified agricultural management has been an important factor in the decline in wildlife habitat quality of lowland grasslands during the latter part of the twentieth century (Vickery et al., 2001). As grass-based agriculture accounts for a high proportion of land-use, particularly in countries such as Ireland (Anderson et al., 2008) and the UK (Vickery et al., 2001), the decline in the grassland biodiversity is likely to represent a major factor of the often noted more general decline in biodiversity within the wider countryside 
(Krebs et al., 1999). Conversely, any agricultural practices associated with a reversal of the trend to reduced grassland biodiversity, has the potential to have a very widespread positive effect. For this reason it is important to understand the major influences on biodiversity within lowland agricultural grasslands, and any factors that influence it. One such factor may be the heterogeneity in arthropod distribution that is introduced by the grazing behaviour of cattle.

The aim of the current study was to quantify the influence of grassland sward islets to arthropod population distribution in cattle pastures. It was hypothesised that islets contain a higher relative density of arthropods than non-islet areas of sward, and that the concentration of arthropods in islets varies in relation to the grazing cycle and sward characteristics, such as the mean sward height. These hypotheses were tested by measuring the abundance of five major arthropod groups (Araneae, Coleoptera, Diptera, Hemiptera and Hymenoptera) in islets and non-islet areas of sward within 27 grassland pastures in the south and east of Ireland. A further hypothesis, that the relative numbers of arthropods in islet and non-islet sward would differ between conventional pastures and those managed according to agri-environment practices, was investigated using a replicated field plot experiment at Teagasc Grange Research Centre.

\section{Methods}


Multi-farm survey

In the summer of 2005, grassland sward islet structure and arthropods populations were investigated in cattle grazed pastures on 26 randomly selected farms from the south and east Irish counties of Carlow, Cork, Kilkenny, Meath, Waterford, Wexford, and Wicklow (Appendix Figure 1). Further details of farm selection, the farms themselves and sampling dates can be found in Anderson et al. (2008), in which the farms utilised in the current study can be identified by site numbers: $1,2,3,4,5,6,8,9,10,11,12,16,17,18,19,22,24,26$, $27,28,31,33,34,36,37,39$. The first farm (1) was sampled on 06 July 2005 and the last (39) on 03 August 2005. On each farm one pasture at approximately the mid-point of the grazing cycle (approximately days 10-14 since last grazing in a typical 21-28 day cycle) and representative of overall farm management, was selected.

In each of the selected pastures, 10 randomly placed suction samples, five from islets and five from non-islet areas of the sward, were taken with a Vortis Insect Suction Sampler (Burkard Manufacturing Co Ltd, Rickmansworth, Hertfordshire, UK) (Arnold, 1994; Brook et al., 2008). Each of the 10 samples was pooled from six ten-second suctions, taken within the relevant sward type, at randomly selected points along a linear transect across the centre of the field. The total area of each sample was $0.12 \mathrm{~m}^{2}$, giving an overall coverage of $0.6 \mathrm{~m}^{2}$ for both islet and non-islet sward, per pasture. The arthropods collected were identified to order and counted. Only the five orders that dominate the macro-arthropod community of these agricultural grasslands (Araneae, Coleoptera, Diptera, Hemiptera and Hymenoptera) were counted. 
For each pasture a number of other variables, later used as explanatory variables in statistical modelling (variable names in italics in parenthesis), were recorded; some related to the pasture itself and some to the farm where it was located. Date (date) was the number of days from the beginning of the year until the day of suction sampling. Farm type (system) was classified as either dairy or non-dairy cattle. Participation in the Irish agri-environment scheme, and nitrogen input level $\left(\mathrm{kg} \mathrm{ha}^{-1}\right)$ of the farm, from both organic and inorganic sources) (totalN) were derived from the Irish National Farm Survey records. Latitude (lat) was obtained from the map location of the farms. Mean sward height (sward $h t$ ) was determined in each pasture by using a Filips Folding Plate Pasture Meter (www.jenquip.co.nz) to measure vegetation height at 50 randomly located points. At each sampling point the sward was visually categorized as either an islet or non-islet, and from this the proportion of the sward covered by islets (prop) was calculated. This could be done because, although islets are most clearly differentiated from the rest of the sward when recently grazed, the relative difference in vegetation height is retained throughout the grazing cycle (MacDiarmid \& Watkin, 1972; Norman \& Green, 1958). Total plant species richness (plant) was measured within each pasture by recording all plant species within 50 randomly located circular quadrats of $0.03 \mathrm{~m}^{2}$ (total area sampled per pasture $=1.5 \mathrm{~m}^{2}$ ). A habitat survey was carried out on each farm, following the Draft Habitat Survey Guidelines (The Heritage Council, 2005) using the classification of habitats followed (Fossitt, 2000). Further details of the habitat survey can be found in the Ag-Biota project report (Purvis et al., 2009). As farm access was granted for individual farms and not neighbouring land, habitat surveys were conducted at the farm scale. The resulting data were combined with information from aerial photographs to calculate the area of different habitats. The areas were used with the Shannon diversity index to calculate the habitat diversity on each farm (habitat div), as well 
as to calculate the percentage of the farm area that was not used in agricultural production (non-crop).

\section{Pasture management experiment}

Use was made of a single-site field plot experiment located at Teagasc (The Irish Agriculture and Food Development Authority) Grange Research Centre, Co Meath in Ireland (longitude $6^{\circ} 40^{\prime} 4^{\prime \prime}$, latitude $53^{\circ} 31^{\prime} 14^{\prime \prime} \mathrm{N}$, Irish grid reference N884530) to test the hypothesis that the distribution of arthropods relative to grassland sward islets would differ between pastures managed with conventional and agri-environment practices. The original experiment was established in 1997 to compare the agronomic performance of a conventional management system for suckler beef production with a system compatible with the Irish agrienvironment scheme, the Rural Environment Protection System (REPS) (Emerson \& Gillmor, 1999). Prior to setting up the experiment, the site had been managed intensively as grazed pasture. The experiment was set out with four blocks, each of which contained the two treatments, with three 0.28 ha paddocks in each treatment. The conventional suckler beef system had a stocking rate of $0.65 \mathrm{ha} / \mathrm{cow}$ unit, with $225 \mathrm{~kg}$ of inorganic nitrogen applied per hectare per year; REPS compatible system had $0.82 \mathrm{ha} / \mathrm{cow}$ unit and $88 \mathrm{~kg} \mathrm{~N} \mathrm{ha}^{-1} \mathrm{yr}^{-1}$. The stocking rates were average values over time and across the experimental paddocks, as cattle were only found in four paddocks at any one time. The paddocks of each block-treatment combination were grazed by four separate, self-contained suckler herds. The experiment was grazed between April and November, in a fixed sequence with reference to treatment and 
block. As a result, individual paddocks were grazed approximately every 21-28 days, with each grazed for between 2 and 3 days on each occasion.

Sward and arthropod sampling within each grazing paddock was done on 27 June 2005 and 26 August 2005. Sward height was measured with the pasture meter at 50 randomly placed points within each paddock. Arthropod sampling was carried out with a Vortis suction sampler. One islet and one non-islet sample were taken, each randomly placed and each consisting of five, ten second suctions. The area sampled in both islet and non-islet sward was $0.1 \mathrm{~m}^{2}$ per paddock. The arthropods collected were separated into their orders and numbers of Araneae, Coleoptera, Hemiptera, Hymenoptera were counted.

Statistical analysis

All statistical modelling was performed using R version 2.9.2 (R Development Core Team, 2009), and in all cases significance was taken at the $\alpha=0.05$ level.

Statistical analysis: multi-farm survey

The difference in mean sward height between islets and non-islet areas in the 27 sampled pastures was investigated using linear regression. Islet sward height was modelled as the response variable with non-islet sward height as the explanatory variable.

The density of the five major arthropod orders in islets and non-islets were compared with linear mixed models using the $\mathrm{R}$ function lme from the nlme package (Pinheiro et al., 
2009). Arthropod abundance was modelled as the response variable, with sub-habitat type (islet or non-islet) and sward height as explanatory variables with farm identity as a random (block) effect. Prior to modelling the response variables (arthropod group abundance) were $\log (\ln )$ transformed and then tested for normality using the Shapiro-Wilk test. In all cases these data conformed to normality.

Generalised linear models using the glm function were used to investigate the relationship between various characteristics of the sites and the proportion of the catch of each arthropod group that were collected in islets compared with non-islet areas. The cbind function was used to combine the abundance data for the islets and non-islets into a new matrix response variable that quantified the proportional incidence in islets. This was modelled with quasibinomial (Araneae, Coleoptera, Diptera, Hemiptera) or binomial (Hymenoptera) error structure, defined using the family directive, and therefore with a logit link function.

The response variable was modelled with the following explanatory variables: system, lat, totalN, non-crop, habitat div, plant, sward ht, prop, and date. Initially models containing all the explanatory variables were used to test for significant interaction terms. Then a maximal model was created with all the explanatory variables and any interaction terms that showed significance. Subsequently, step-wise model simplification was carried out by the sequential removal of non-significant terms (Crawley, 2007), with tests of deletion, using the anova function to determine whether removal of terms was justified.

\section{Statistical analysis: Pasture management experiment}


The proportion of arthropods (Araneae, Coleoptera, Hemiptera (all individuals), Hemiptera (all individuals minus immature aphids) and Hymenoptera) found in islets and the relative abundance in islets was modelled with the lmer function. Two Hemiptera response variables were modelled, because immature aphids appeared to have a very large influence on the data. The response variable was a matrix generated using the cbind function to combine the numbers collected in islet and non-islet, and binomial error structure was defined using the family directive. The explanatory variables used were treatment and mean sward height, as well as their interaction. The nested experimental structure was accounted for by using three random effects: sample date, nested within paddock, nested within treatment (i.e. treatment/paddock/date).

\author{
Results \\ Multi-farm survey - proportion of islets and arthropods
}

The proportion of the multi-farm survey fields covered by islets and the proportion of the five arthropod group populations in islets, estimated from the numbers collected and the relative area of islets, were in all cases found to show distributions that were not significantly different from normality, when tested with the Shapiro-Wilk normality test. Islets covered a median proportion of 0.25 of cattle grazed fields with a range of between 0.10 and 0.52 (Figure 2). The proportion of invertebrate abundance in islets was in all cases higher than 0.25 with median proportions in islets as follows: Araneae 0.45; Coleoptera 0.43; Diptera 0.52; Hemiptera 0.46; Hymenoptera 0.45 (Figure 2). 
Multi-farm survey - Relationship between islet and non-islet sward height

The linear regression model of islet sward height (response) against non-islet sward height (explanatory) from the 26 sites, was highly significant $\left(\mathrm{F}_{1,24}=30.69 \mathrm{P}<0.001, \mathrm{r}^{2}=0.54\right)$. The model estimated an intercept of 5.95 and slope of 0.96 . The standard error for the slope estimate was 0.17 with $95 \%$ confidence intervals \pm 0.36 . Therefore a slope of unity is very close to and well within the $95 \%$ confidence intervals for the estimated slope.

\section{Multi-farm survey - relative arthropod abundance in islets and non-islets}

Modelling of the number of arthropods in the 26 pastures gave very similar results for all five groups. All models indicated that there were significantly more individuals collected in islets than in non-islet areas, and that there was a significant negative interaction between sward height and sub-habitat type (Table 1). In all models the interaction indicated that while there was a significant positive sward height effect for non-islet areas, there was no sward effect with islets themselves.

\section{Multi-farm survey - site variables}


The generalised linear models of the proportion of individuals collected in islets showed some similarity between the arthropod orders (Table 2). They indicated that for Araneae, Coleoptera, Hemiptera and Hymenoptera there were significant negative relationships with mean sward height (Figure 3). There were significant positive relationships with the proportion of the sward covered by islets for the Araneae, Hemiptera and Hymenoptera (Table 2). There were significant positive relationships with farm habitat diversity for Coleoptera and Hymenoptera (Table 2). For the Hemiptera there was a system effect with a greater proportion of individuals in islets in non-dairy than dairy sites. Models for the Diptera showed little similarity with those for the other orders, with a significant negative relationship with date, such that the proportion of Diptera in islets declined during the sampling period (Table 2). The minimal adequate model for Hymenoptera was the most complex and revealed several additional significant parameters. These were the proportion of non-cropped habitats and an interaction of non-cropped area and sward height (Table 2). The non-crop-sward interaction indicated that although there was a significant negative sward height effect, the strength of this decreased as the proportion of non-crop habitats increased.

Using model parameter estimates, and mean observed values for non-sward height variables, estimates can be made of the average proportion of arthropods collected within islets at the two extremes of sward height sampled, $5 \mathrm{~cm}$ and $12 \mathrm{~cm}$ (Figure 3). Proportions at $5 \mathrm{~cm}$ were as follows: Araneae 0.81, Coleoptera, 0.83, Hemiptera, 0.80 and Hymenoptera 0.81. At $12 \mathrm{~cm}$ the figures had fallen to: Araneae 0.61, Coleoptera 0.55, Hemiptera, 0.56, and Hymenoptera 0.57 .

Pasture management experiment 
Models of the proportional incidence of arthropods within islets, indicated that for the Araneae, Coleoptera (REPS treatment only), Hemiptera and Hymenoptera there were significant negative effects with sward height (Table 3). The models for Coleoptera and Hemiptera indicated significant treatment-sward height interactions. For both groups there was a strongly significant negative sward height effect in the REPS treatment, and in the conventional treatment there was no sward height effect. When modelling was repeated with Hemiptera data from which aphid nymph abundance had been subtracted there were no significant interactions with only sward height indicating a decline in the proportion of individuals in islets as sward height increased. In addition to sward height, treatment itself was significant for Coleoptera and Hemiptera, and in both cases the proportion of individuals in islets was greater for the REPS treatment than in the conventional.

\section{Discussion}

Grassland sward islets, areas of longer sward resulting from reduced grazing activity by cattle, were found to cover a mean proportion of 0.24 of the area of the 26 cattle pastures surveyed. This is very much within the range of islet cover reported from other studies, which ranged between 0.10 and 0.47 (Castle \& MacDaid, 1972; Gibb et al., 1997; MacLusky, 1960; Marsh \& Campling, 1970; Tayler \& Large, 1955; Tayler \& Rudman, 1966). Previous studies of islets have mainly concentrated on their agronomic effects and here we make little comment from that perspective. However the relationship between sward height within and outside of islets does give support to the suggestion of MacDiarmid and Watkin (1972) that 
once islets are established grazing occurs on islets and non-islet sward. The regression indicated that the difference in sward height between islets and surrounding sward was 5.95 $\mathrm{cm}$, compared to the $4.06 \mathrm{~cm}$ (given as 1.6 inches) reported by MacDiarmid and Watkin (1972), and that the slope was very close to 1, suggesting that the difference in sward height remains constant across a range of mean sward heights.

The main focus of this study was the arthropod populations associated with islets. Although islets covered a mean proportion of 0.24 of pastures, calculations from the numbers of arthropods collected and the relative area of islets indicated that the proportion of total arthropod populations found in islets varied between 0.45 and 0.54 . Therefore it appears that approximately half the individual arthropods were concentrated in only a quarter of the area of the pastures. These figures were of course average findings from 26 fields in approximately the middle of the grazing cycle, and did not take into account the effect of changing sward height. However they do give an indication of the importance of islets in determining the distribution of arthropod populations within pastures. As such cattle, and similarly some other vertebrate herbivores, have an important role in terms of generating sward structural diversity and consequently enhancing arthropod and other forms of biodiversity (Davidson \& Lightfoot, 2006; Knapp et al., 1999).

The greater numbers of all arthropod groups within islets, relative to non-islets, even with sward height included as a covariate, indicated that the concentration within islets was due to more than the sampling of an increased volume of habitat related to sward height. The longer sward of the islets may enhance the abundance of invertebrates through niche availability and microclimate, as has been suggested for grassland vegetation height more generally (Andrzejewska, 1965; Baines et al., 1998; Bell et al., 2001; Cattin et al., 2003; Curry, 1987b; Morris, 2000; Morris \& Lakhani, 1979; Morris \& Rispin, 1987). 
The dung present at the centre of the islets may be directly attracting some species, particularly dung breeding species of Diptera and Coleoptera (Curry, 1987a; Skidmore, 1991). These in turn would attract their predators and parasites, including many staphylinid Coleoptera, some Araneae and many parasitoid Hymenoptera. The dung may provide an increase of nutrients such as nitrogen in the locality of the islet. This may be important in increasing the abundance of herbivores, particularly the sap-sucking Hemiptera, for which nitrogen is often limiting (Andrzejewska, 1976; Denno \& Roderick, 1990; Olechowicz, 1976). Again, a greater abundance of herbivores will attract predators and parasites.

The longer sward may have an important effect on microclimate, buffering the effect of temperature variation and increasing humidity (Bossenbroek et al., 1977a, b; D'Hulster \& Desender, 1982; De Keer et al., 1989; Luff, 1965b), which may be beneficial for a range of arthropods. The buffering of temperature may be particularly important in winter and islets may be a valuable overwintering site for some arthropods (D'Hulster \& Desender, 1984; Dennis et al., 1994; Desender, 1982). The humidity may be especially important for soil microarthropods, such as Collembola and Acari, and their many predators such as the staphylinid genus Stenus and Araneae of the family Linyphiidae (Curry, 1987a).

Spiders such as some of the Linyphiidae may also be dependent on the longer vegetation provided by islets for suitable sites for their webs (Bell et al., 2001; Harwood et al., 2003). The longer sward may provide additional feeding niches, for example flower and seed heads which are important for a range of Hemiptera and Coleoptera. There would also be a greater number of potential sites for leaf and stem mining species, which include many Diptera (Curry, 1987a). Of course islets may also provide a greater degree of shelter from vertebrate predators such as birds. 
Although islets were found to hold higher densities of arthropods than non-islet areas of sward, generalised linear modelling indicated that the proportion collected in islets relative to non-islet sward was related to several factors. The most important of these appeared to be mean sward height, followed by the percentage of sward covered by islets, and there was also some evidence for differences related to farm habitat diversity, percentage of non-crop habitat and agri-environment sward management. In the Araneae, Hemiptera and Hymenoptera there was a positive relationship between the proportion of the sward covered by islets and the proportion of individuals collected in islets. This was not due to a sampling effect as the two sub-habitats were sampled equally. Perhaps with a greater density of islets arthropods have greater chance to encounter an islet, and therefore more of the arthropods are located within them. In the Coleoptera and Hymenoptera there was a positive relationship between farm habitat diversity and the proportion of individuals collected in islets which could arise if farmers who have a more diverse farm structure were more tolerant of well defined islet structure.

The higher concentration of individuals of Coleoptera and Hemiptera within islets in the REPS system may indicate that lower intensity grazing systems generate greater level of small-scale heterogeneity. It is widely considered that heterogeneity is very important for conserving biodiversity (Benton et al., 2003; Morris, 2000; Woodcock et al., 2009). Thus islets together with other factors, such as vegetation diversity, may contribute to the aims of agri-environment schemes to restore biodiversity within agricultural systems.

The proportion of Araneae, Coleoptera, Hemiptera and Hymenoptera collected from islets declined as the mean sward height increased. Estimates based on the generalised linear modelling indicated that at the extremes of sward height sampled, and given equal sampling in the two sub-habitats approximately $80 \%$ of arthropods would be found in islets when 
overall mean sward height was $5 \mathrm{~cm}$ but this would fall to about $59 \%$ in swards with a overall mean of $12 \mathrm{~cm}$ (equivalent to approximately $3 \%$ for each $\mathrm{cm}$ ). Sward height data (Appendix Table 1) from eight of the paddocks at the Teagasc Grange field site, measured on 10 dates between May and September 2003, indicated that in only 8 out of 80 date-paddock combinations was the sward height greater than $12 \mathrm{~cm}$. Therefore a high level of arthropod aggregation in islets is likely to remain through most if not all the grazing cycle.

Nevertheless, the contrast of arthropod density between islets and non-islets was clearly reduced as the mean sward height increased between grazing events.

What might explain the change in the contrast in relative density? Once established, islets can remain as distinct structures for many months (MacDiarmid \& Watkin, 1972; Norman \& Green, 1958). Although some grazing of islets does occur (MacDiarmid \& Watkin, 1972; Marten \& Donker, 1964a) they are generally much less disturbed than nonislet areas and thus can represent a long-term refuge of suitable habitat for many invertebrates, This constancy of resource can explain the lack of a sward height effect with arthropod abundance in islets. In contrast, non-islet sward is grazed and therefore disturbed to a much great extent. When strongly grazed the very short grass, rather analogous to a domestic lawn, is likely to be a poor habitat, with reduced ecological niches, food resources and altered microclimate (Helden \& Leather, 2004; Morris, 2000). As grazed sward recovers from grazing, the suitability of the habitat will increase again. Recovery after grazing may well explain the positive response of arthropod abundance to sward height in the non-islet sub-habitat. Thus the contrast in the relative abundance between islets and non-islets is likely to be related to a change in the contrast of habitat suitability.

The ecological constancy of islets means they have the potential to be refugia from grazing events. Humbert (2009) recently presented a very similar idea when proposing that 
un-cut patches should be left after mowing as a way of maintaining arthropod biodiversity in cut grasslands. Given this, the common and often, although not universally, recommended practice of topping (mowing) after grazing, to return a sward to a uniform height (Barry et al., 2002; Boswell, 1971; Castle \& MacDaid, 1972; MacLusky, 1960; Norman \& Green, 1958), is likely to be detrimental to grassland arthropod biodiversity. Such topping is likely to lead to the death and/or migration of much of arthropod population (Humbert et al., 2009). The purpose of this work is not to comment on the agronomic value or otherwise of topping but rather to comment from an ecological perspective. Given this and the apparent importance of islets for grassland arthropods, could other ecological benefits be accrued from encouraging islet structure in cattle pastures? Arthropods fulfil many roles in ecological communities: herbivores, detritivores, predators, as well as being food for many consumers at higher levels in food webs. They are also important at providing many ecosystem services beneficial to humans, such as predation and parasitism of pests, pollination, nutrient cycling and decomposition processes (Altieri, 1999). Therefore any management that promotes islets and so arthropod populations may be expected to have benefits to ecological community structure and processes. One specific benefit would be for farmland birds, for which there has been considerable concern over recent years due to widespread population declines linked to intensive farming practices (Krebs et al., 1999; Robinson \& Sutherland, 2002; Vickery et al., 2001). Larger arthropod populations would provide a greater food supply for insectivorous birds. In addition the heterogeneous sward structure itself may be beneficial for birds. Ground feeding birds find prey more accessible in short swards but more abundant in longer swards and therefore the interface of longer and shorter swards, such as around islets, may be valuable foraging areas (Douglas et al., 2009). 
Agricultural grasslands cover large areas of Ireland and other northern European countries (Anderson et al., 2008; Vickery et al., 2001). As such they have a role in the maintenance of biodiversity within the wider countryside, both as habitats in themselves and as a forming much of the matrix in which many other more species rich habitats such as semi-natural habitat fragments, hedgerows and field margins are embedded (Donald \& Evans, 2006). Therefore any enhancement of grassland biodiversity at the local scale has the potential to have wider landscape consequences. It is therefore important that islets and other factors that operate at the local scale are understood more and that related biodiversity positive management options are encouraged.

\section{Acknowledgements}

This work was part of the Ag-Biota Project, funded by the Environmental Protection Agency, Ireland (2001-CD/B1-M1) through the ERTDI Programme under the National Development Plan (2000- 2006). Tim Carnus, Rónan Gleeson, Julie Melling and Yasmine Lovic gave excellent assistance in the collection and sorting of samples. We thank Michael Drennan and Teagasc for permitting access to their suckler beef grassland experiments at Teagasc Grange, and Anne Kinsella for her assistance in the random selection of commercial farms from the National Farm Survey (NFS) database for the purpose of the 26-site farm survey. We are also very grateful to all the farmers who allowed us access to their farms and for their cooperation throughout our work. 


\section{References}

Altieri, M.A. (1999) The ecological role of biodiversity in agroecosystems. Agriculture, Ecosystems and Environment, 74, 19-31.

Anderson, A., Helden, A., Carnus, T., Gleeson, R., Sheridan, H., McMahon, B., Melling, J., Lovic, Y., \& Purvis, G. (2008) Arthropod biodiversity of agricultural grassland in south and east Ireland: introduction, sampling sites and Araneae. Bulletin of the Irish Biogeographical Society, 32, 142-159.

Andrzejewska, L. (1965) Stratification and its dynamics in meadow communities of Auchenorrhyncha (Homoptera). Ekologia Polska - Seria A, 13, 685-715.

Andrzejewska, L. (1976) The influence of mineral fertilization on the meadow phytophagous fauna. Polish Ecological Studies, 2, 93-109.

Arnold, A.J. (1994) Insect suction sampling without nets, bags or filters. Crop Protection, 13, 73-76.

Baines, M., Hambler, C., Johnson, P.J., Macdonald, D.W., \& Smith, H. (1998) The effects of arable field margin management on the abundance and species richness of Araneae (spiders). Ecography, 21, 74-86.

Barry, P., Culleton, N., \& Fox, R. (2002). Management systems for organic spring milk production. In Principles of Successful Organic Farming. (eds N. Culleton, P. Barry, R. Fox, R. Schulte \& J. Finn), pp. 38-45. Teagasc, Dublin.

Bayram, A. \& Luff, M.L. (1993) Winter Abundance and Diversity of Lycosids (Lycosidae, Araneae) and Other Spiders in Grass Tussocks in a Field Margin. Pedobiologia, 37, 357-364. 
Bell, J.R., Wheater, C.P., \& Cullen, W.R. (2001) The implications of grassland and heathland management for the conservation of spider communities: a review. Journal of Zoology, 255, $377-387$.

Benton, T.G., Vickery, J.A., \& Wilson, J.D. (2003) Farmland biodiversity: is habitat heterogeneity the key? Trends in Ecology and Evolution, 18, 182-188.

Boom, C.J. \& Sheath, G.W. (2008) Migration of gastrointestinal nematode larvae from cattle faecal pats onto grazable herbage. Veterinary Parasitology, 157, 260-266.

Bosker, T., Hoekstra, N.J., \& Lantinga, E.A. (2002) The influence of feeding strategy on growth and rejection of herbage around dung pats and their decomposition. Journal of Agricultural Science, 139, 213-221.

Bossenbroek, P., Kessler, A., Liem, A.S.N., \& Vlijm, L. (1977a) Experimental-Analysis of Significance of Tuft-Structures as a Shelter for Invertebrate Fauna, with Respect to WindVelocity and Temperature. Journal of Zoology, 182, 7-16.

Bossenbroek, P., Kessler, A., Liem, A.S.N., \& Vlijm, L. (1977b) Significance of Plant Growth-Forms as Shelter for Terrestrial Animals. Journal of Zoology, 182, 1-6.

Boswell, C.C. (1971) Fouling of pastures by grazing cattle. Journal of the British Grassland Society, 26, 194.

Brook, A.J., Woodcock, B.A., Sinka, M., \& Vanbergen, A.J. (2008) Experimental verification of suction sampler capture efficiency in grasslands of differing vegetation height and structure. Journal of Applied Ecology, 45, 1357-1363.

Castle, M.E. \& MacDaid, E. (1972) The decomposition of cattle dung and its effect on pasture. Journal of the British Grassland Society, 27, 133-137. 
Cattin, M.F., Blandenier, G., Banasek-Richter, C., \& Bersier, L.F. (2003) The impact of mowing as a management strategy for wet meadows on spider (Araneae) communities. Biological Conservation, 113, 179-188.

Chesson, P. (2000) Mechanisms of maintenance of species diversity. Annual Review of Ecology and Systematics, 31, 343-366.

Crawley, M.J. (2007) The R Book. John Wiley \& Sons, Ltd, Chichester.

Curry, J.P. (1987a) The invertebrate fauna of grassland and its influence on productivity. I. The composition of the fauna. Grass and Forage Science, 42, 103-120.

Curry, J.P. (1987b) The invertebrate fauna of grassland and its influence on productivity. II. Factors affecting the abundance and composiiton of the fauna. Grass and Forage Science, $\mathbf{4 2}$, 197-212.

D'Hulster, M. \& Desender, K. (1982) Ecological and faunal studies on Coleoptera in agricultural land III. Seasonal abundance and hibernation of Staphylinidae in the grassy edge of a pasture. Pedobiologia, 23, 403-414.

D'Hulster, M. \& Desender, K. (1984) Ecological and faunal studies of Coleoptera in agricultural land IV. Hibernation of Staphylinidae in agro-ecosystems. Pedobiologia, 26, 6573.

Davidson, A.D. \& Lightfoot, D.C. (2006) Keystone rodent interactions: prairie dogs and kangaroo rats structure the biotic composition of a desertified grassland. Ecography, 29, 755765.

De Keer, R., Alderweireldt, M., Decleer, K., Segers, H., Desender, K., \& Maelfait, J.-P. (1989) Horizontal distribution of the spider fauna of intensively grazed pastures under the influence of diurnal activity and grass height. Journal of Applied Entomology, 107, 455-473. 
De Keer, R., Desender, K., D'Hulster, M., \& Maelfait, J.-P. (1986) The importance of edges for the spider and beetle fauna of a pasture. Annales de la Société Royale Zoologique de Belgique, 116, 92-93.

Dennis, P., Thomas, M.B., \& Sotherton, N.W. (1994) Structural features of field boundaries which influence the overwintering densities of beneficial arthropod predators. Journal of Applied Ecology, 31, 361-370.

Dennis, P., Young, M.R., \& Gordon, I.J. (1998) Distribution and abundance of small insects and arachnids in relation to structural heterogeneity of grazed, indigenous grasslands. Ecological Entomology, 23, 253-264.

Denno, R.F. \& Roderick, G.K. (1990) Population biology of planthoppers. Annual Review of Entomology, 35, 489-520.

Desender, K. (1982) Ecological and faunal studies on Coleoptera in agricultural land II. Hibernation of Carabidae in agro-ecosystems. Pedobiologia, 23, 295-303.

Desender, K., Alderweireldt, M., \& Pollet, M. (1989) Field edges and their importance for polyphagous predatory arthropods. Mededelingen van de Faculteit Landbouw, Rijksuniversiteit Gent, 54, 823-833.

Donald, P.F. \& Evans, A.D. (2006) Habitat connectivity and matrix restoration: the wider implications of agri-environment schemes. Journal of Applied Ecology, 43, 209-218. Douglas, D.J.T., Vickery, J.A., \& Benton, T.G. (2009) Improving the value of field margins as foraging habitat for farmland birds. Journal of Applied Ecology, 46, 353-362.

Emerson, H.J. \& Gillmor, D.A. (1999) The Rural Environment Protection Scheme of the Republic of Ireland. Land Use Policy, 16, 235-245.

Fossitt, J.A. (2000) A Guide to Habitats in Ireland. Heritage Council, Kilkenny. 
Gibb, M.J., Huckle, C.A., Nuthall, R., \& Rook, A.J. (1997) Effect of sward surface height on intake and grazing behaviour by lactating Holstein Friesian cows. Grass and Forage Science, 52, 309-321.

Greenhalgh, J.F.D. \& Reid, G.W. (1968) The effects of grazing intensity on herbage consumption and animal production. III. Dairy cows grazed at two intensities on clean or contaminated pasture. Journal of Agricultural Science, 71, 223-228.

Harwood, J.D., Sunderland, K.D., \& Symondson, W.O.C. (2003) Web-location by linyphiid spiders: prey-specific aggregation and foraging strategies. Journal of Animal Ecology, 72, 745-756.

Haynes, R.J. \& Williams, P.H. (1993) Nutrient Cycling and Soil Fertility in the Grazed Pasture Ecosystem. Advances in Agronomy, 49, 119-199.

Helden, A.J. \& Leather, S.R. (2004) Biodiversity on urban roundabouts - Hemiptera, management and the species-area relationship. Basic and Applied Ecology, 5, 367-377. Humbert, J.Y., Ghazoul, J., \& Walter, T. (2009) Meadow harvesting techniques and their impacts on field fauna. Agriculture Ecosystems \& Environment, 130, 1-8.

Knapp, A.K., Blair, J.M., Briggs, J.M., Collins, S.L., Hartnett, D.C., Johnson, L.C., \& Towne, E.G. (1999) The keystone role of bison in north American tallgrass prairie - Bison increase habitat heterogeneity and alter a broad array of plant, community, and ecosystem processes. Bioscience, 49, 39-50.

Krebs, J.R., Wilson, J.D., Bradbury, R.B., \& Siriwardena, G.M. (1999) The second Silent Spring? Nature, 400, 611-612.

Lantinga, E.A., Kuening, J.A., Groenwold, J., \& Deenen, P.J.A.G. (1987). Distribution of excreted nitrogen by grazing cattle and its effects on sward quality, herbage production and 
utilization. . In Animal Manure on Grassland and Fodder Crops (ed H.G. Meer vd), pp. 103117. Martinus Nijhoff Publishers, Dordrecht.

Luff, M.L. (1965a) A list of Coleoptera occurring in grass tussocks. Entomologist's Monthly Magazine, 101, 240-245.

Luff, M.L. (1965b) The morphology and microclimate of Dactylis glomerata tussocks. Journal of Ecology, 53, 771-787.

Luff, M.L. (1966) The abundance and diversity of the beetle fauna of grass tussocks. Journal of Animal Ecology, 35, 189-208.

MacDiarmid, B.N. \& Watkin, B.R. (1971) The cattle dung patch. 1. Effect of dung patches on yield and botanical composition of surrounding and underlying pasture. Journal of the British Grassland Society, 26, 239-245.

MacDiarmid, B.N. \& Watkin, B.R. (1972) The cattle dung patch. 3. Distribution and rate of decay of dung patches and their influence on grazing bahaviour. Journal of the British Grassland Society, 27, 48-54.

MacLusky, D.S. (1960) Some estimates of the area of pasture fouled by the excreta of dairy cows. Journal of the British Grassland Society, 15, 181-188.

Maelfait, J.-P. \& De Keer, R. (1990) The border zone of an intensively grazed pasture as a corridor for spiders Araneae. Biological Conservation, 54, 223-238.

Marsh, R. \& Campling, R.C. (1970) Fouling of pastures by dung. Herbage Abstracts, 40, 123-130.

Marten, G.C. \& Donker, J.D. (1964a) Selective grazing induced by animal excreta. I. Evidence of occurrence and superficial remedy. Journal of Dairy Science, 47, 773-776. Marten, G.C. \& Donker, J.D. (1964b) Selective grazing induced by animal excreta. II. Investigation of a causal theory. Journal of Dairy Science, 47, 871-874. 
McNaughton, S.J. (1984) Grazing Lawns - Animals in Herds, Plant Form, and Coevolution. American Naturalist, 124, 863-886.

Mikola, J., Setala, H., Virkajarvi, P., Saarijarvi, K., Ilmarinen, K., Voigt, W., \& Vestberg, M. (2009) Defoliation and patchy nutrient return drive grazing effects on plant and soil properties in a dairy cow pasture. Ecological Monographs, 79, 221-244.

Morris, M.G. (2000) The effects of structure and its dynamics on the ecology and conservation of arthropods in British grasslands. Biological Conservation, 95, 129-142.

Morris, M.G. \& Lakhani, K.H. (1979) Responses of grassland invertebrates to management by cutting. I Species diversity of Hemiptera. Journal of Applied Ecology, 16, 77-98.

Morris, M.G. \& Rispin, W.E. (1987) Abundance and diversity of the coleopterous fauna of a calcareous grassland under different cutting regimes. Journal of Applied Ecology, 24, 451465.

Norman, M.J.T. \& Green, J.O. (1958) The local influence of cattle dung and urine upon the yield and botanical composition of permanent pasture. Journal of the British Grassland Society, 13, 39-45.

Olechowicz, E. (1976) The effect of mineral fertilization on insect community of the herbage in a meadow. Polish Ecological Studies, 2, 129-136.

Parish, R. \& Turkington, R. (1990) The colonization of dung pats and molehills in permanent pastures. Canadian Journal of Botany, 68, 1706-1711.

Pearce, E.J. (1948) The invertebrate fauna of grass-tussocks: a suggested line for ecological study. Entomologist's Monthly Magazine, 84, 169-174.

Pinheiro, J., Bates, D., DebRoy, S., \& Sarkar, D. (2009) nlme: Linear and Nonlinear Mixed Effects Models. R package version 3.1-96. 
Plice, M.J. (1951) Sugar versus the intuitive choice of foods by livestock. Agronomy Journal, 43, 341-342.

Purvis, G., Anderson, A., Baars, J.-R., Bolger, T., Breen, J., Connolly, J., Curry, J., Doherty, P., Doyle, M., Finn, J., Geijzendorffer, I., Helden, A., Kelly-Quinn, M., Kennedy, T., Kirwan, L., McDonald, J., McMahon, B., Miksche, D., Santorum, V., Schmidt, O., Sheehan, C., \& Sheridan, H. (2009) Ag-Biota: Monitoring, Functional Significance and Management for the Maintenance and Economic Utilisation of Biodiversity in the Intensively Farmed Landscape. Environmental Protection Agency.

<http://erc.epa.ie/safer/iso19115/displayISO19115.jsp?isoID=108> 24th May 2010, Johnstown Castle, Ireland.

R Development Core Team (2009) R: A language and environment for statistical computing. R Foundation for Statistical Computing, Vienna, Austria. ISBN 3-900051-07-0, URL http://www.R-project.org.

Robinson, R.A. \& Sutherland, W.J. (2002) Post-war changes in arable farming and biodiversity in Great Britain. Journal of Applied Ecology, 39, 157-176.

Rook, A.J. \& Tallowin, J.R.B. (2003) Grazing and pasture management for biodiversity benefit. Animal Research, 52, 181-189.

Schulte, R.P.O., Lantinga, E.A., \& Struik, P.C. (2003) Analysis of the production stability of mixed grasslands I: A conceptual framework for the qualification of production stability in grassland ecosystems. Ecological Modelling, 159, 43-69.

Schwinning, S. \& Parsons, A.J. (1996) Analysis of the coexistence mechanisms for grasses and legumes in grazing systems. Journal of Ecology, 84, 799-813.

Skidmore, P. (1991) Insects of the British Cow Dung Community Field Studies Council. 
Tayler, J.C. \& Large, R.V. (1955) The comparative output of two seeds mixtures. Journal of the British Grassland Society, 10, 341-351.

Tayler, J.C. \& Rudman, J.E. (1966) The distribution of herbage at different heights in 'grazed' and 'dung patch' areas of a sward under two methods of grazing management. Journal of Agricultural Science, 66, 29-39.

The Heritage Council (2005) Draft Habitat Survey Guidelines. A Standard Methology for Habitat Survey and Mapping in Ireland. The Heritage Council.

$<$ http://www.heritagecouncil.ie/fileadmin/user_upload/Publications/Wildlife/HabitatSurveyG uidelines_2_Draft_April_2005.doc $>24$ th May 2010.

Vickery, J.A., Tallowin, J.R., Feber, R.E., Asteraki, E.J., Atkinson, P.W., Fuller, R.J., \& Brown, V.K. (2001) The management of lowland neutral grasslands in Britain: effects of agricultural practices on birds and their food resources. Journal of Applied Ecology, 38, 647664.

Wallis De Vries, M.F., Parkinson, A.E., Dulphy, J.P., Sayer, M., \& Diana, E. (2007) Effects of livestock breed and grazing intensity on biodiversity and production in grazing systems. 4 . Effects on animal diversity. Grass and Forage Science, 62, 185-197.

Weeda, W.C. (1967) The effect of cattle dung patches on pasture growth, botanical composition, and pasture utilisation. New Zealand Journal of Agricultural Research, 10, 150159.

Woodcock, B.A., Potts, S.G., Tscheulin, T., Pilgrim, E., Ramsey, A.J., Harrison-Cripps, J., Brown, V.K., \& Tallowin, J.R. (2009) Responses of invertebrate trophic level, feeding guild and body size to the management of improved grassland field margins. Journal of Applied Ecology, 46, 920-929. 


\author{
Woodcock, B.A., Potts, S.G., Westbury, D.B., Ramsay, A.J., Lambert, M., Harris, S.J., \& \\ Brown, V.K. (2007) The importance of sward architectural complexity in structuring \\ predatory and phytophagous invertebrate assemblages. Ecological Entomology, 32, 302-311.
}

Table 1. Summary of linear mixed model (lme) comparisons of the abundance of arthropods in islets and non-islets, from the 26 sites of the multi-farm survey. Parameter estimates are given in $\log (\ln )$ values. Degrees of freedom for the estimates of the slope parameter estimates 
were 23; so for a given slope parameter the equivalent numerator and denominator d.f. (e.g. sward height) would be 1 and 23 degrees of freedom. Significance is indicated as: *** $\mathrm{p}<0.001, * * \mathrm{p}<0.01, * \mathrm{p}<0.05$.

\begin{tabular}{|l|l|l|l|l|}
\hline $\begin{array}{l}\text { Arthropod } \\
\text { group }\end{array}$ & \multicolumn{4}{|c|}{ Parameter estimates } \\
\hline & $\begin{array}{l}\text { intercept (non- } \\
\text { islets) }\end{array}$ & islets & sward height & $\begin{array}{l}\text { islet:sward } \\
\text { height } \\
\text { interaction }\end{array}$ \\
\hline Araneae & $2.539 * * *$ & $2.739 * * *$ & $0.176^{*}$ & $-0.213^{* *}$ \\
\hline Coleoptera & $1.986 * * *$ & $3.096^{* * *}$ & $0.203^{* * *}$ & $-0.257^{* * *}$ \\
\hline Diptera & $3.336 * * *$ & $2.844^{* *}$ & $0.195^{*}$ & $-0.214^{*}$ \\
\hline Hemiptera & $2.568^{* * *}$ & $2.037^{* * *}$ & $0.229^{* *}$ & $-0.184^{* *}$ \\
\hline Hymenoptera & $2.645^{* * *}$ & $2.210^{* * *}$ & $0.160^{* *}$ & $-0.176^{* * *}$ \\
\hline
\end{tabular}

Table 2. Minimal adequate models from generalised linear modelling ( $\mathrm{glm}$ ) of the proportion of arthropods (abundance in islets/total abundance) collected in islets at the 26 multi-farm survey sites. Parameter estimates given in terms of logits. The logit estimates (x) can be 
converted to proportions as follows: $\exp (\mathrm{x}) /(1+(\exp (\mathrm{x}))$. Degrees of freedom (d.f.) are given; for a given slope parameter (e.g. Araneae sward ht) the equivalent numerator and denominator d.f. would be 1 and 23 degrees of freedom. Significance is indicated as: *** $\mathrm{p}<0.001, * * \mathrm{p}<0.01, * \mathrm{p}<0.05$.

\begin{tabular}{|l|l|l|l|l|}
\hline Arthropod & Model & Parameter estimates & d.f. & Deviance \\
& & (intercept \pm explanatory & explained \\
& & variables $)$ & $(\%)$ \\
\hline Araneae & $\sim$ sward ht + prop & $2.665^{* * *}-0.291^{* * *}+2.868^{* *}$ & 23 & 50.3 \\
\hline Coleoptera & $\sim$ habitat div + sward ht & $2.223^{* * *}+0.376^{*}-0.195^{* * *}$ & 23 & 67.0 \\
\hline Diptera & $\sim$ date & $9.969^{* *}-0.043^{*}$ & 24 & 23.6 \\
\hline Hemiptera & $\sim$ system + sward ht + & $2.845^{* * *}+0.445^{*}-0.335^{* * *}+$ & 22 & 63.6 \\
& prop & $2.925^{* *}$ & & \\
\hline Hymenoptera & $\sim$ non-crop + habitat div & $2.466^{* * *}-5.810^{*}+0.434^{* *}-$ & 20 & \\
\hline & + sward ht + prop + & $0.327^{* * *}+1.915^{* *}+0.933^{* *}$ & & \\
\hline
\end{tabular}

Table 3. Minimal adequate models from generalised linear mixed modelling (lmer) of the proportion of arthropods collected in islets from the pasture management experiment (Teagasc Grange). Proportion of arthropods in islets (abundance in islets/total abundance) 
with parameter estimates given in terms of logits. The logit estimates $(\mathrm{x})$ can be converted to proportions as follows: $\exp (\mathrm{x}) /(1+(\exp (\mathrm{x}))$. Model structure was such that it was equivalent to having numerator and denominator degrees of freedom for parameter estimates of 1 and 4 . $((2$ treatments $)-1=1 ;(3$ plots/treatment $)-1=2 \times 2$ treatments $)$.

\begin{tabular}{llll}
\hline Arthropod group & Model & Parameter estimates & Deviance \\
& & (intercept \pm explanatory & explained \\
& & variables) & $(\%)$ \\
\hline Araneae & sward ht & $1.000^{* *}-0.032^{*}$ & 1.9 \\
Coleoptera & treatment + sward ht + & $1.595^{* * *}+1.177^{*}-$ & 38.1 \\
& treatment:sward ht & $0.056-0.116^{* *}$ & \\
Hemiptera (all & treatment + sward ht + & $1.091^{* * *}+1.256^{* * *}-$ & 20.1 \\
individuals) & treatment:sward ht & $0.037^{*}-0.083^{* * *}$ & \\
Hemiptera & sward ht & $1.706^{* * *}-0.095^{* * *}$ & 56.0 \\
(minus aphid & & & \\
juveniles) & & & \\
Hymenoptera & sward ht & & \\
\hline
\end{tabular}

Figure legends

Figure 1. A well defined islet in a cattle-grazed pasture 
Figure 2. Boxplots showing the median proportion of the total overall populations from the multi-farm survey pastures of Araneae (aran), Coleoptera (col), Diptera (dipt), Hemiptera (hem) and Hymenoptera (hym) estimated to be found in islets. Proportion data were estimated from the numbers collected and the relative area of islets. Also shown is the proportion of field area covered by islets (islets) from the same 26 sites. Boxplots show the median values as the dark horizontal lines and figures; $25^{\text {th }}$ and $75^{\text {th }}$ percentiles as the top and bottom of the boxes. The dashed lines show either 1.5 times the interquartile range together with outliers as small circles, or if there are no outliers, the maximum and minimum values.

Figure 3. Change with sward height, in the proportion of all individuals of Araneae, Coleoptera, Hemiptera and Hymenoptera collected in islets at the multi-farm survey sites. For the Hemiptera the dashed line indicates non-dairy and the solid line dairy sites.

Appendix Figure 1. Location of the 26 multi-farm survey sites (closed circles) and the pasture management experiment at Teagasc Grange (open triangle). 
Figure 1.

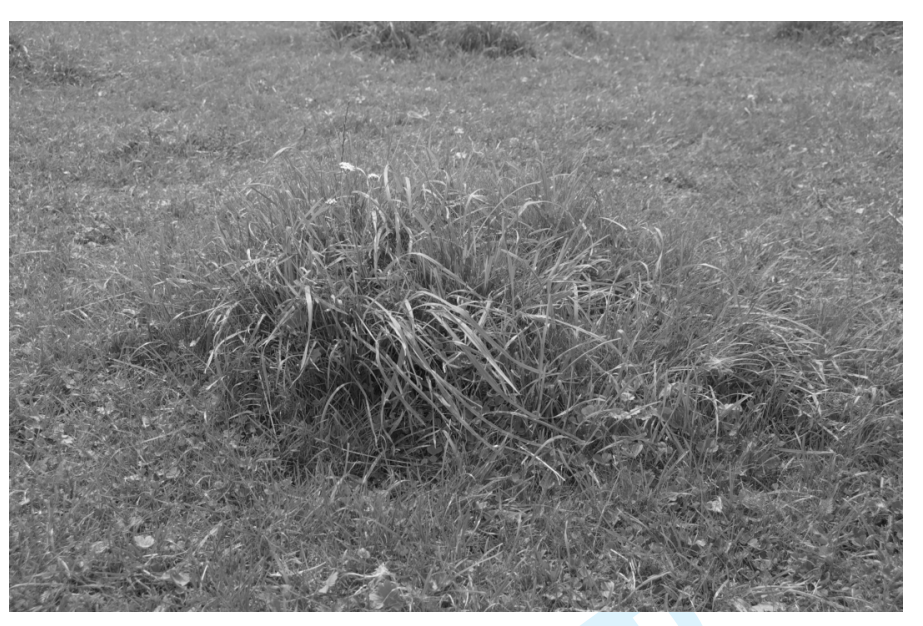

Figure 2. 


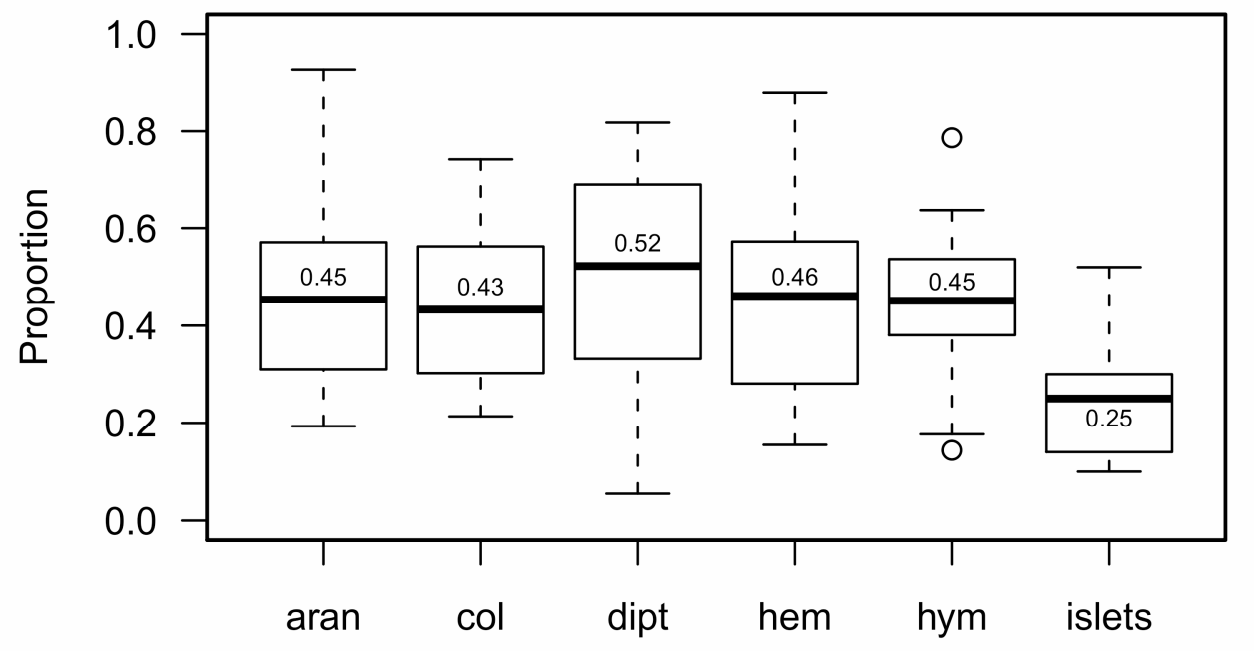

Figure 3, 


\section{Araneae}

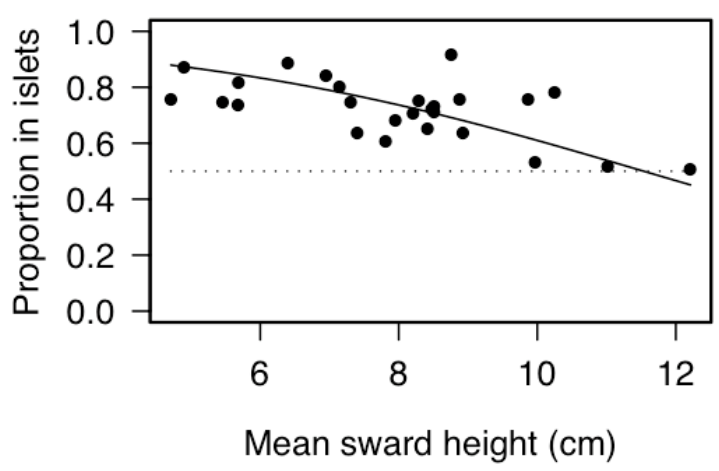

Hemiptera

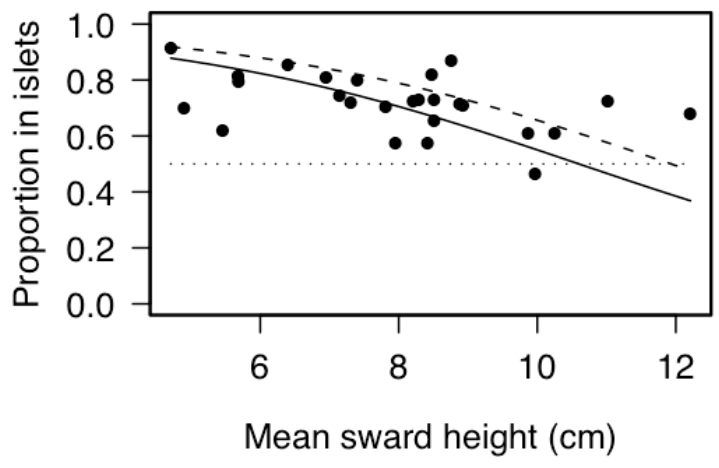

Coleoptera

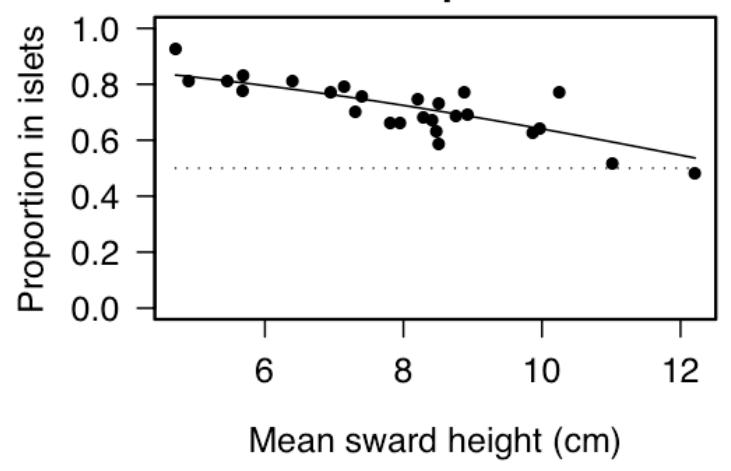

Hymenoptera

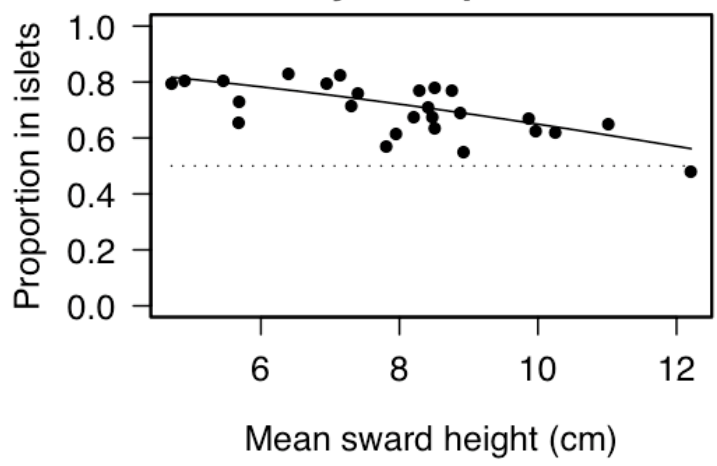


Appendix Table 1. Mean sward height in eight of the Teagasc Grange paddocks on ten dates between May and September 2003. Values over $12 \mathrm{~cm}$ are shown in bold.

\begin{tabular}{|c|c|c|c|c|c|c|c|c|c|c|}
\hline \multirow[t]{3}{*}{ Paddock name } & \multicolumn{10}{|c|}{ Date } \\
\hline & 7 & 27 & 11 & 17 & 3 & 15 & 30 & 14 & 26 & 9 \\
\hline & May & May & June & June & July & July & July & Aug & Aug & Sept \\
\hline Conventional M1 & 6.9 & 5.0 & 8.5 & 8.1 & 6.1 & 10.4 & 5.9 & 9.4 & 14.0 & 14.7 \\
\hline Conventional M2 & 7.2 & 4.9 & 9.0 & 10.5 & 7.5 & 8.7 & 5.6 & 10.0 & 13.3 & 14.7 \\
\hline REPS M1 & 8.6 & 4.2 & 9.0 & 9.0 & 7.4 & 7.3 & 13.0 & 6.3 & 9.9 & 11.2 \\
\hline REPS M2 & 7.2 & 6.1 & 8.1 & 10.2 & 6.9 & 11.0 & 14.0 & 7.3 & 10.3 & 11.2 \\
\hline Conventional F1 & 5.3 & 7.8 & 6.5 & 5.8 & 7.0 & 5.1 & 7.4 & 12.7 & 6.6 & 8.8 \\
\hline Conventional F2 & 5.2 & 6.0 & 5.4 & 3.7 & 5.7 & 9.3 & 6.4 & 12.2 & 6.6 & 7.0 \\
\hline REPS C1 & 5.4 & 6.7 & 4.9 & 5.0 & 8.7 & 9.8 & 5.1 & 8.9 & 5.0 & 6.7 \\
\hline REPS C2 & 5.9 & 6.8 & 6.4 & 5.9 & 6.7 & 9.2 & 5.5 & 9.2 & 5.6 & 5.4 \\
\hline
\end{tabular}




\section{Appendix Figure 1.}

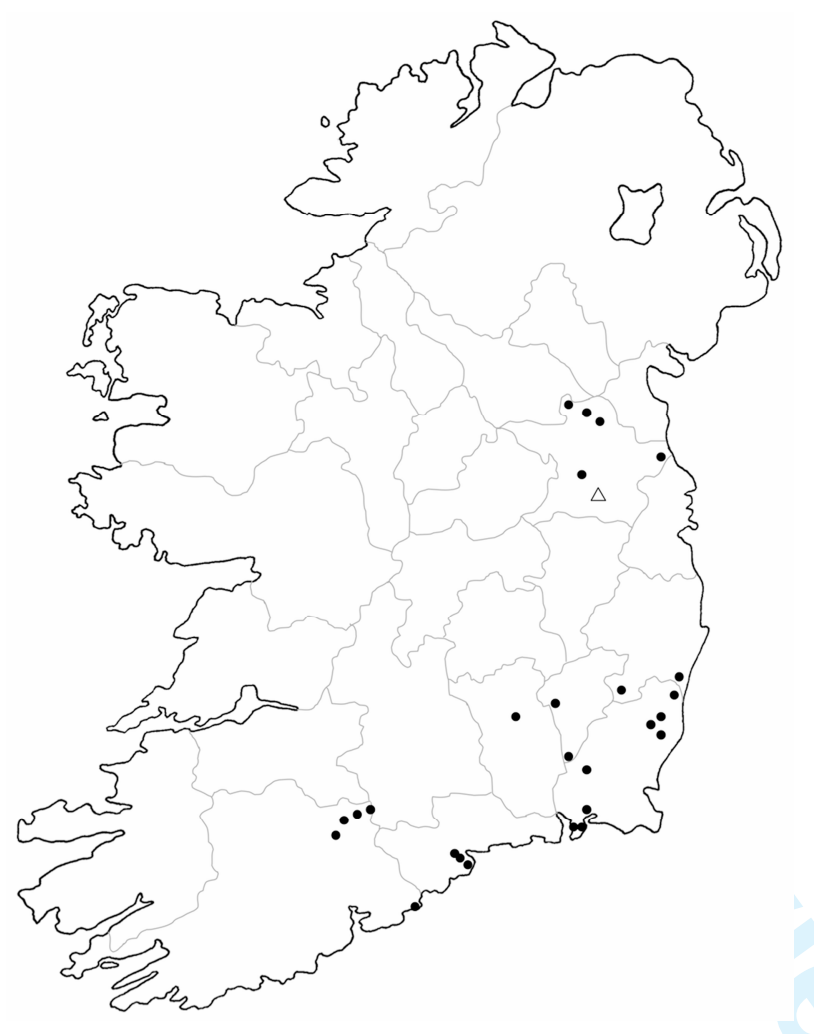




\title{
The role of grassland sward islets in the distribution of arthropods in cattle pastures.
}

\author{
ALVIN J. HELDEN ${ }^{1,2}$, ANNETTE ANDERSON ${ }^{2}$ HELEN SHERIDAN $^{2}$ \& GORDON \\ PURVIS $^{2}$ \\ ${ }^{1}$ Animal and Environmental Research Group, Department of Life Sciences, Anglia Ruskin \\ University, East Road, Cambridge, CB1 1PT, UK \\ ${ }^{2}$ UCD School of Agriculture, Food Science and Veterinary Medicine, University College \\ Dublin, Belfield, Dublin 4, Ireland
}

Address for correspondence: Dr Alvin Helden, Animal and Environmental Research Group, Department of Life Sciences, Anglia Ruskin University, East Road, Cambridge, CB1 1PT, UK. Tel: +44 1223363271 Fax: +44 1223417712 e-mail: a.helden@anglia.ac.uk

Running title: Arthropods and sward islets

\author{
Abstract \\ 1. It is well documented that cattle reduce their grazing activity in the vicinity of cattle \\ dung, which gives rise to distinct patches, or islets as they have been termed, of \\ longer sward. The influence of such islets on pasture utilisation and agronomic \\ performance has been widely studied, but very little information is available \\ concerning their influence on grassland biodiversity.
}


2. In this study the abundance and distribution of arthropods in relation to islets was assessed, using suction sampling, at 26 commercial farms and in a replicated pasture management experiment in the south and east of Ireland.

3. Islets were found to cover approximately $24 \%$ of pastures and to contain between 40 and $50 \%$ of arthropod individuals.

4. Islets consistently contained a higher density of arthropods, even when the difference in mean sward height between islets and more strongly grazed sward was accounted for. The relative concentration of arthropods in islets declined with increasing mean sward height, which may be related to a change in the recovery of well-grazed nonislet sward. Islets appear to act as refugia from sward removal,

5. The potential importance of islets in maintaining arthropod biodiversity within intensively grazed pastures and the wider landscape within intensive grass-based farming areas is discussed, particularly with reference to standard agronomic practices such as sward topping and chain harrowing, which aim to remove the sward heterogeneity created by grazing livestock.

Keywords. insects, spiders, biodiversity, agriculture, grazing, refugia, spatial heterogeneity

\begin{tabular}{l} 
Deleted: Grassland islets, \\
Arthropods \\
\hline Deleted: $\mathrm{B}$ \\
\hline Deleted: $\mathrm{G}$ \\
\hline Deleted: $\mathrm{R}$
\end{tabular}




\section{Introduction}

It has been known for many years that grazing by cattle is reduced, although not completely avoided, in the immediate vicinity of cattle dung (Marsh \& Campling, 1970; Norman \&

behaviour, including the smell of the dung and the coarseness, sugar content and nutrient content of the grass, but there have be no definitive answers (Bosker et al., 2002; MacDiarmid \& Watkin, 1972; Marsh \& Campling, 1970; Marten \& Donker, 1964a, b; Plice, 1951). It may be that the dung causes an initial rejection in the proximal sward, With, consequent differences in the chemical or physical characteristics the grazed and ungrazed vegetation maintaining the rejection by cattle (MacLusky, 1960; McNaughton, 1984; Norman \& Green, 1958). Whatever the present reasons for such behaviour in grazing cattle, the underlying evolutionary explanation may lie in avoidance of infection by gastrointestinal parasite larvae, the distribution of which tends to remain highly concentrated in the vicinity of dung patches during the grazing season (Boom \& Sheath, 2008).

The result of this behaviour by cattle in relatively intensive grasslands, is that distinct patches of longer sward are typically found around dung patches (Figure 1) (MacDiarmid \& Watkin, 1972). These patches have been termed islets, due to the contrast between them and the more heavily grazed sward surrounding them, (Desender, 1982; Maelfait \& De Keer, 1990). Although islets have taller vegetation, the botanical composition is initially little changed from the remaining sward (MacDiarmid \& Watkin, 1971; Norman \& Green, 1958; Parish \& Turkington, 1990). However, some studies suggest that the spatial heterogeneity created by such patches, especially in soil nutrient status (Haynes \& Williams, 1993; Lantinga et al., 1987), is likely to influence relative plant population dynamics and the
Field Code Changed

Deleted: but $\mathrm{t}$

Deleted: hen

Deleted: some consequent

Deleted: changes to

Deleted:

Deleted: as well as the presence of higher food quality promoted by recent defoliation in more heavily grazed areas,

Deleted: s

Field Code Changed

Field Code Changed

Field Code Changed

Field Code Changed 
longer-term co-existence of sward species (Chesson, 2000; Schulte et al., 2003; Schwinning

\& Parsons, 1996).

Islets have been estimated to cover between 10 and $47 \%$ of pasture area and to persist for between a few months to over a year, although both these characteristics vary with grazing intensity, rainfall and management such as cutting (Boswell, 1971; Castle \&

Field Code Changed MacDaid, 1972; Gibb et al., 1997; MacLusky, 1960; Marsh \& Campling, 1970; Marten \& Donker, 1964a; Norman \& Green, 1958; Tayler \& Large, 1955; Weeda, 1967). The extent and persistence of islets has often been considered to represent a reduction in productivity and consequently has stimulated many studies from an agronomic perspective (Bosker et al. 2002; Castle \& MacDaid, 1972; Greenhalgh \& Reid, 1968; MacLusky, 1960; Marsh \& Campling, 1970; Marten \& Donker, 1964a; Tayler \& Rudman, 1966). It is also a major reason for the practices of sward topping to reduce physical sward heterogeneity (and control weeds) and chain harrowing to re-distribute surface dung (Barry et al., 2002; Boswell, 1971;

Field Code Changed MacLusky, 1960; Norman \& Green, 1958; Weeda, 1967).

In contrast there has been little work done on the possible ecological effects of islets. Mikola (2009) recently reported a major study of the ecological effects of localised dungdeposition on plant and soil faunal communities in grazed pasture. Desender (1982),

Field Code Changed

Field Code Changed

Field Code Changed

Field Code Changed Desender et al. (1989) and D'Hulster and Desender (1982, 1984) found evidence that islets may be important overwintering sites for Carabidae and Staphylinidae, particularly as they are not trampled by cattle and cover a relatively large area. Some spiders (Araneae) are also thought to use islets for overwintering (De Keer et al., 1986; Desender et al., 1989; Maelfait \& De Keer, 1990). De Keer et al. (1989) found that the contrast in microhabitat conditions between the vegetation within and outside islets resulted in differences in the growing season distribution, abundance and behaviour of different spider species. The present authors are not 
aware of any other studies specifically focused on the distribution of above-ground arthropods relative to islets, although their value in maintaining heterogeneity and botanical diversity in grassland is well recognised Chesson, 2000; Rook \& Tallowin, 2003; Wallis De Vries et al., 2007), Neither does there appear to have been any direct investigation in islets terms of above ground arthropod groups apart from Araneae, Carabidae and Staphylinidae.

There have been a number of studies of the arthropods found in more permanent tussock structures, including those in upland areas, in lowland field margins and in beetle banks. Unlike islets, these tussocks are associated with the growth form of specific grass or similar monocot plant species, such as the grasses Dactylis glomerata L. (Luff, 1965b), Nardus stricta L. (Dennis et al., 1998) and Holcus lanatus L. (Bossenbroek et al., 1977b).

The importance of tussocks for arthropods, particularly in terms of overwintering, has long been recognised (Bayram \& Luff, 1993; Luff, 1965a; Luff, 1966; Pearce, 1948). It has been suggested that their value to arthropods is particularly associated with their sheltered microclimate, including reduced temperature and humidity fluctuation (Bossenbroek et al., 1977a, b; Luff, 1965b). At a larger habitat scale, the presence of tussocks helps to create heterogeneity within grasslands, which is considered a highly important factor in determining arthropod and other biodiversity (Benton et al., 2003; Dennis et al., 1998; Morris, 2000; Rook \& Tallowin, 2003; Woodcock et al., 2007). A reduction in structural diversity associated with intensified agricultural management has been an important factor in the decline in wildlife habitat quality of lowland grasslands during the latter part of the twentieth century (Vickery et al., 2001). As grass-based agriculture accounts for a high proportion of land-use, particularly in countries such as Ireland (Anderson et al., 2008) and the UK (Vickery et al., 2001), the decline in the grassland biodiversity is likely to represent a major factor of the often noted more general decline in biodiversity within the wider countryside 
(Krebs et al., 1999). Conversely, any agricultural practices associated with a reversal of the trend to reduced grassland biodiversity, has the potential to have a very widespread positive effect. For this reason it is important to understand the major influences on biodiversity within lowland agricultural grasslands, and any factors that influence it. One such factor may be the heterogeneity in arthropod distribution that is introduced by the grazing behaviour of cattle.

The aim of the current study was to quantify the influence of grassland sward islets to arthropod population distribution in cattle pastures. It was hypothesised that islets contain a higher relative density of arthropods than non-islet areas of sward, and that the concentration of arthropods in islets varies in relation to the grazing cycle and sward characteristics, such as the mean sward height. These hypotheses were tested by measuring the abundance of five major arthropod groups (Araneae, Coleoptera, Diptera, Hemiptera and Hymenoptera) in islets and non-islet areas of sward within 27 grassland pastures in the south and east of Ireland. A further hypothesis, that the relative numbers of arthropods in islet and non-islet sward would differ between conventional pastures and those managed according to agri-environment practices, was investigated using a replicated field plot experiment at Teagasc Grange Research Centre.

\section{Methods}


Multi-farm survey

In the summer of 2005, grassland sward islet structure and arthropods populations were investigated in cattle grazed pastures on 26 randomly selected farms from the south and east Irish counties of Carlow, Cork, Kilkenny, Meath, Waterford, Wexford, and Wicklow (Appendix Figure 1). Further details of farm selection, the farms themselves and sampling dates can be found in Anderson et al. (2008), in which the farms utilised in the current study can be identified by site numbers: $1,2,3,4,5,6,8,9,10,11,12,16,17,18,19,22,24,26$, $27,28,31,33,34,36,37,39$. The first farm (1) was sampled on 06 July 2005 and the last (39) on 03 August 2005. On each farm one pasture at approximately the mid-point of the grazing cycle (approximately days 10-14 since last grazing in a typical 21-28 day cycle) and representative of overall farm management, was selected.

In each of the selected pastures, 10 randomly placed suction samples, five from islets and five from non-islet areas of the sward, were taken with a Vortis Insect Suction Sampler (Burkard Manufacturing Co Ltd, Rickmansworth, Hertfordshire, UK) (Arnold, 1994; Brook et al., 2008). Each of the 10 samples was pooled from six ten-second suctions, taken within the relevant sward type, at randomly selected points along a linear transect across the centre of the field. The total area of each sample was $0.12 \mathrm{~m}^{2}$, giving an overall coverage of $0.6 \mathrm{~m}^{2}$ for both islet and non-islet sward, per pasture. The arthropods collected were identified to order and counted. Only the five orders that dominate the macro-arthropod community of these agricultural grasslands (Araneae, Coleoptera, Diptera, Hemiptera and Hymenoptera) were counted. 
For each pasture a number of other variables, later used as explanatory variables in statistical modelling (variable names in italics in parenthesis), were recorded; some related to the pasture itself and some to the farm where it was located. Date (date) was the number of days from the beginning of the year until the day of suction sampling. Farm type (system) was classified as either dairy or non-dairy cattle. Participation in the Irish agri-environment scheme, and nitrogen input level $\left(\mathrm{kg} \mathrm{ha}^{-1}\right)$ of the farm, from both organic and inorganic sources) (totalN) were derived from the Irish National Farm Survey records. Latitude (lat) was obtained from the map location of the farms. Mean sward height (sward ht) was determined in each pasture by using a Filips Folding Plate Pasture Meter (www.jenquip.co.nz) to measure vegetation height at 50 randomly located points. At each sampling point the sward was visually categorized as either an islet or non-islet, and from this the proportion of the sward covered by islets (prop) was calculated. This could be done because, although islets are most clearly differentiated from the rest of the sward when recently grazed, the relative difference in vegetation height is retained throughout the grazing cycle (MacDiarmid \& Watkin, 1972; Norman \& Green, 1958). Total plant species richness (plant) was measured within each pasture by recording all plant species within 50 randomly located circular quadrats of $0.03 \mathrm{~m}^{2}$ (total area sampled per pasture $=1.5 \mathrm{~m}^{2}$ ). A habitat survey was carried out on each farm, following the Draft Habitat Survey Guidelines (The Heritage Council, 2005) using the classification of habitats followed (Fossitt, 2000). Further details of the habitat survey can be found in the Ag-Biota project report (Purvis et al., 2009). As farm access was granted for individual farms and not neighbouring land, habitat surveys were conducted at the farm scale. The resulting data were combined with information from

Deleted: aerial photographs to calculate the area of different habitats. The areas were used with the Shannon diversity index to calculate the habitat diversity on each farm (habitat div), as well 
as to calculate the percentage of the farm area that was not used in agricultural production (non-crop)

\section{Pasture management experiment}

Use was made of a single-site field plot experiment located at Teagasc (The Irish Agriculture and Food Development Authority) Grange Research Centre, Co Meath in Ireland (longitude $6^{\circ} 40^{\prime} 4^{\prime \prime}$, latitude $53^{\circ} 31^{\prime} 14^{\prime \prime} \mathrm{N}$, Irish grid reference N884530) to test the hypothesis that the distribution of arthropods relative to grassland sward islets would differ between pastures managed with conventional and agri-environment practices. The original experiment was established in 1997 to compare the agronomic performance of a conventional management system for suckler beef production with a system compatible with the Irish agrienvironment scheme, the Rural Environment Protection System (REPS) (Emerson \& Gillmor, 1999). Prior to setting up the experiment, the site had been managed intensively as grazed pasture. The experiment was set out with four blocks, each of which contained the two treatments, with three 0.28 ha paddocks in each treatment. The conventional suckler beef system had a stocking rate of $0.65 \mathrm{ha} / \mathrm{cow}$ unit, with $225 \mathrm{~kg}$ of inorganic nitrogen applied per hectare per year; REPS compatible system had $0.82 \mathrm{ha} / \mathrm{cow}$ unit and $88 \mathrm{~kg} \mathrm{~N} \mathrm{ha}^{-1} \mathrm{yr}^{-1}$. The stocking rates were average values over time and across the experimental paddocks, as cattle were only found in four paddocks at any one time. The paddocks of each block-treatment combination were grazed by four separate, self-contained suckler herds. The experiment was grazed between April and November, in a fixed sequence with reference to treatment and 
block. As a result, individual paddocks were grazed approximately every 21-28 days, with each grazed for between 2 and 3 days on each occasion.

Sward and arthropod sampling within each grazing paddock was done on 27 June 2005 and 26 August 2005. Sward height was measured with the pasture meter at 50 randomly placed points within each paddock. Arthropod sampling was carried out with a Vortis suction sampler. One islet and one non-islet sample were taken, each randomly placed and each consisting of five, ten second suctions. The area sampled in both islet and non-islet sward was $0.1 \mathrm{~m}^{2}$ per paddock. The arthropods collected were separated into their orders and numbers of Araneae, Coleoptera, Hemiptera, Hymenoptera were counted.

\section{Statistical analysis}

All statistical modelling was performed using $\mathrm{R}$ version 2.9.2 (R Development Core Team, 2009), and in all cases significance was taken at the $\alpha=0.05$ level.

Statistical analysis: multi-farm survey

The difference in mean sward height between islets and non-islet areas in the 27 sampled pastures was investigated using linear regression. Islet sward height was modelled as the response variable with non-islet sward height as the explanatory variable.

The density of the five major arthropod orders in islets and non-islets were compared with linear mixed models using the $\mathrm{R}$ function lme from the nlme package (Pinheiro et al., 
2009). Arthropod abundance was modelled as the response variable, with sub-habitat type (islet or non-islet) and sward height as explanatory variables with farm identity as a random (block) effect. Prior to modelling the response variables (arthropod group abundance) were $\log (\ln )$ transformed and then tested for normality using the Shapiro-Wilk test. In all cases these data conformed to normality.

Generalised linear models using the glm function were used to investigate the relationship between various characteristics of the sites and the proportion of the catch of each arthropod group that were collected in islets compared with non-islet areas. The cbind function was used to combine the abundance data for the islets and non-islets into a new matrix response variable that quantified the proportional incidence in islets. This was modelled with quasibinomial (Araneae, Coleoptera, Diptera, Hemiptera) or binomial (Hymenoptera) error structure, defined using the family directive, and therefore with a logit link function.

The response variable was modelled with the following explanatory variables: system, lat, totalN, non-crop, habitat div, plant, sward ht, prop, and date. Initially models containing all the explanatory variables were used to test for significant interaction terms. Then a maximal model was created with all the explanatory variables and any interaction terms that showed significance. Subsequently, step-wise model simplification was carried out by the sequential removal of non-significant terms (Crawley, 2007), with tests of deletion, using the anova function to determine whether removal of terms was justified.

Statistical analysis: Pasture management experiment 
The proportion of arthropods (Araneae, Coleoptera, Hemiptera (all individuals),

Hemiptera (all individuals minus immature aphids) and Hymenoptera) found in islets and the relative abundance in islets was modelled with the lmer function. Two Hemiptera response variables were modelled, because immature aphids appeared to have a very large influence on the data. The response variable was a matrix generated using the cbind function to combine the numbers collected in islet and non-islet, and binomial error structure was defined using the family directive. The explanatory variables used were treatment and mean sward height, as well as their interaction. The nested experimental structure was accounted for by using three random effects: sample date, nested within paddock, nested within treatment (i.e. treatment/paddock/date)

Deleted:

Results
Multi-farm survey - proportion of islets and arthropods

The proportion of the multi-farm survey fields covered by islets and the proportion of the five arthropod group populations in islets, estimated from the numbers collected and the relative area of islets, were in all cases found to show distributions that were not significantly different from normality, when tested with the Shapiro-Wilk normality test. Islets covered a median proportion of 0.25 of cattle grazed fields with a range of between 0.10 and 0.52 (Figure 2). The proportion of invertebrate abundance in islets was in all cases higher than 0.25 with median proportions in islets as follows: Araneae 0.45; Coleoptera 0.43; Diptera 0.52; Hemiptera 0.46; Hymenoptera 0.45 (Figure 2). 
Multi-farm survey - Relationship between islet and non-islet sward height

Multi-farm survey - relative arthropod abundance in islets and non-islets

Modelling of the number of arthropods in the 26 pastures gave very similar results for all five groups. All models indicated that there were significantly more individuals collected in islets than in non-islet areas, and that there was a significant negative interaction between sward height and sub-habitat type (Table 1). In all models the interaction indicated that while there was a significant positive sward height effect for non-islet areas, there was no sward effect with islets themselves. 
The generalised linear models of the proportion of individuals collected in islets showed some similarity between the arthropod orders (Table 2). They indicated that for Araneae, Coleoptera, Hemiptera and Hymenoptera there were significant negative relationships with mean sward height (Figure 3). There were significant positive relationships with the proportion of the sward covered by islets for the Araneae, Hemiptera and Hymenoptera (Table 2). There were significant positive relationships with farm habitat diversity for Coleoptera and Hymenoptera (Table 2). For the Hemiptera there was a system effect with a greater proportion of individuals in islets in non-dairy than dairy sites. Models for the Diptera showed little similarity with those for the other orders, with a significant negative relationship with date, such that the proportion of Diptera in islets declined during the sampling period (Table 2). The minimal adequate model for Hymenoptera was the most complex and revealed several additional significant parameters. These were the proportion of non-cropped habitats and an interaction of non-cropped area and sward height (Table 2). The non-crop-sward interaction indicated that although there was a significant negative sward height effect, the strength of this decreased as the proportion of non-crop habitats increased.

Using model parameter estimates, and mean observed values for non-sward height variables, estimates can be made of the average proportion of arthropods collected within islets at the two extremes of sward height sampled, $5 \mathrm{~cm}$ and $12 \mathrm{~cm}$ (Figure 3). Proportions at 5_cm were as follows: Araneae 0.81, Coleoptera, 0.83, Hemiptera, 0.80 and Hymenoptera 0.81. At $12 \mathrm{~cm}$ the figures had fallen to: Araneae 0.61, Coleoptera 0.55, Hemiptera, 0.56, and Hymenoptera 0.57 .

Pasture management experiment 


\section{Discussion}

Grassland sward islets, areas of longer sward resulting from reduced grazing activity by cattle, were found to cover a mean proportion of 0.24 of the area of the 26 cattle pastures surveyed. This is very much within the range of islet cover reported from other studies, which ranged between 0.10 and 0.47 (Castle \& MacDaid, 1972; Gibb et al., 1997; MacLusky, 1960; Marsh \& Campling, 1970; Tayler \& Large, 1955; Tayler \& Rudman, 1966). Previous studies of islets have mainly concentrated on their agronomic effects and here we make little comment from that perspective. However the relationship between sward height within and outside of islets does give support to the suggestion of MacDiarmid and Watkin (1972) that 
once islets are established grazing occurs on islets and non-islet sward. The regression indicated that the difference in sward height between islets and surrounding sward was 5.95 $\mathrm{cm}$, compared to the $4.06 \mathrm{~cm}$ (given as 1.6 inches) reported by MacDiarmid and Watkin (1972), and that the slope was very close to 1, suggesting that the difference in sward height

The main focus of this study was the arthropod populations associated with islets.

Although islets covered a mean proportion of 0.24 of pastures, calculations from the numbers of arthropods collected and the relative area of islets indicated that the proportion of total arthropod populations found in islets varied between 0.45 and 0.54 . Therefore it appears that approximately half the individual arthropods were concentrated in only a quarter of the area of the pastures. These figures were of course average findings from 26 fields in approximately the middle of the grazing cycle, and did not take into account the effect of changing sward height. However they do give an indication of the importance of islets in determining the distribution of arthropod populations within pastures. As such cattle, and similarly some other vertebrate herbivores, have an important role in terms of generating sward structural diversity and consequently enhancing arthropod and other forms of biodiversity (Davidson \& Lightfoot, 2006; Knapp et al., 1999).

The greater numbers of all arthropod groups within islets, relative to non-islets, even with sward height included as a covariate, indicated that the concentration within islets was due to more than the sampling of an increased volume of habitat related to sward height. The longer sward of the islets may enhance the abundance of invertebrates through niche availability and microclimate, as has been suggested for grassland vegetation height more generally (Andrzejewska, 1965; Baines et al., 1998; Bell et al., 2001; Cattin et al., 2003; Curry, 1987b; Morris, 2000; Morris \& Lakhani, 1979; Morris \& Rispin, 1987).
Deleted : for Hymenoptera

Deleted: for Diptera, with the figures of 0.47 for Coleoptera, 0.48 for Hemiptera and 0.49 for Araneae

Field Code Changed

Deleted: in a similar way 
The dung present at the centre of the islets may be directly attracting some species, particularly dung breeding species of Diptera and Coleoptera (Curry, 1987a; Skidmore, 1991). These in turn would attract their predators and parasites, including many staphylinid Coleoptera ${ }_{2}$ some Araneae and many parasitoid Hymenoptera. The dung may provide an increase of nutrients such as nitrogen in the locality of the islet. This may be important in increasing the abundance of herbivores, particularly the sap-sucking Hemiptera, for which nitrogen is often limiting (Andrzejewska, 1976; Denno \& Roderick, 1990; Olechowicz, 1976). Again, a greater abundance of herbivores will attract predators and parasites.

The longer sward may have an important effect on microclimate, buffering the effect of temperature variation and increasing humidity (Bossenbroek et al., 1977a, b; D'Hulster \& Desender, 1982; De Keer et al., 1989; Luff, 1965b), which may be beneficial for a range of arthropods. The buffering of temperature may be particularly important in winter and islets may be a valuable overwintering site for some arthropods (D'Hulster \& Desender, 1984; Dennis et al., 1994; Desender, 1982). The humidity may be especially important for soil microarthropods, such as Collembola and Acari, and their many predators such as the staphylinid genus Stenus and Araneae of the family Linyphiidae (Curry, 1987a).

Spiders such as some of the Linyphiidae may also be dependent on the longer vegetation provided by islets for suitable sites for their webs (Bell et al., 2001; Harwood et al., 2003). The longer sward may provide additional feeding niches, for example flower and seed heads which are important for a range of Hemiptera and Coleoptera. There would also be a greater number of potential sites for leaf and stem mining species, which include many Diptera (Curry, 1987a). Of course islets may also provide a greater degree of shelter from vertebrate predators such as birds. 
Although islets were found to hold higher densities of arthropods than non-islet areas of sward, generalised linear modelling indicated that the proportion collected in islets relative to non-islet sward was related to several factors. The most important of these appeared to be mean sward height, followed by the percentage of sward covered by islets, and there was also some evidence for differences related to farm habitat diversity, percentage of non-crop habitat and agri-environment sward management. In the Araneae, Hemiptera and Hymenoptera there was a positive relationship between the proportion of the sward covered by islets and the proportion of individuals collected in islets. This was not due to a sampling effect as the two sub-habitats were sampled equally. Perhaps with a greater density of islets arthropods have greater chance to encounter an islet, and therefore more of the arthropods are located within them. In the Coleoptera and Hymenoptera there was a positive relationship between farm habitat diversity and the proportion of individuals collected in islets which could arise if farmers who have a more diverse farm structure were more tolerant of well defined islet structure.

The higher concentration of individuals of Coleoptera and Hemiptera within islets in the REPS system may indicate that lower intensity grazing systems generate greater level of small-scale heterogeneity. It is widely considered that heterogeneity is very important for conserving biodiversity (Benton et al., 2003; Morris, 2000; Woodcock et al., 2009). Thus

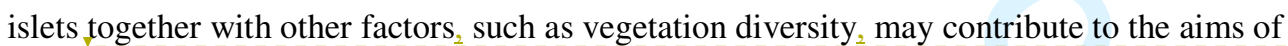
Deleted: (Benton et al., 2003; Morris, 2000) agri-environment schemes to restore biodiversity within agricultural systems.

The proportion of Araneae, Coleoptera, Hemiptera and Hymenoptera collected from islets declined as the mean sward height increased. Estimates based on the generalised linear modelling indicated that at the extremes of sward height sampled, and given equal sampling in the two sub-habitats approximately $80 \%$ of arthropods would be found in islets when 
overall mean sward height was $5 \mathrm{~cm}$ but this would fall to about $59 \%$ in swards with a overall mean of $12 \mathrm{~cm}$ (equivalent to approximately $3 \%$ for each $\mathrm{cm}$ ). Sward height data (Appendix Table 1) from eight of the paddocks at the Teagasc Grange field site measured on 10 dates between May and September 2003, indicated that in only 8 out of 80 date-paddock combinations was the sward height greater than $12 \mathrm{~cm}$. Therefore a high level of arthropod aggregation in islets is likely to remain through most if not all the grazing cycle.

Nevertheless, the contrast of arthropod density between islets and non-islets was clearly reduced as the mean sward height increased between grazing events.

What might explain the change in the contrast in relative density? Once established, islets can remain as distinct structures for many months (MacDiarmid \& Watkin, 1972; Norman \& Green, 1958). Although some grazing of islets does occur (MacDiarmid \& Watkin, 1972; Marten \& Donker, 1964a) they are generally much less disturbed than nonislet areas and thus can represent a long-term refuge of suitable habitat for many invertebrates, This constancy of resource can explain the lack of a sward height effect with arthropod abundance in islets. In contrast, non-islet sward is grazed and therefore disturbed to a much great extent. When strongly grazed the very short grass, rather analogous to a domestic lawn, is likely to be a poor habitat, with reduced ecological niches, food resources and altered microclimate (Helden \& Leather, 2004; Morris, 2000). As grazed sward recovers from grazing, the suitability of the habitat will increase again. Recovery after grazing may well explain the positive response of arthropod abundance to sward height in the non-islet sub-habitat. Thus the contrast in the relative abundance between islets and non-islets is likely to be related to a change in the contrast of habitat suitability.

The ecological constancy of islets means they have the potential to be refugia from grazing events. Humbert (2009) recently presented a very similar idea when proposing that
Deleted: D

Deleted: the field site

Deleted: , of the sward height of eight of the paddocks,

Field Code Changed 
un-cut patches should be left after mowing as a way of maintaining arthropod biodiversity in cut grasslands. Given this, the common and often, although not universally, recommended practice of topping (mowing) after grazing, to return a sward to a uniform height (Barry et al., 2002; Boswell, 1971; Castle \& MacDaid, 1972; MacLusky, 1960; Norman \& Green, 1958), is likely to be detrimental to grassland arthropod biodiversity. Such topping is likely to lead to the death and/or migration of much of arthropod population (Humbert et al., 2009).

The purpose of this work is not to comment on the agronomic value or otherwise of topping but rather to comment from an ecological perspective. Given this and the apparent importance of islets for grassland arthropods, could other ecological benefits be accrued from encouraging islet structure in cattle pastures? Arthropods fulfil many roles in ecological communities: herbivores, detritivores, predators, as well as being food for many consumers at higher levels in food webs. They are also important at providing many ecosystem services beneficial to humans, such as predation and parasitism of pests, pollination, nutrient cycling and decomposition processes (Altieri, 1999). Therefore any management that promotes islets and so arthropod populations may be expected to have benefits to ecological community structure and processes. One specific benefit would be for farmland birds, for which there has been considerable concern over recent years due to widespread population declines linked to intensive farming practices (Krebs et al., 1999; Robinson \& Sutherland, 2002; Vickery et al., 2001). Larger arthropod populations would provide a greater food supply for insectivorous birds. In addition the heterogeneous sward structure itself may be beneficial for birds. Ground feeding birds find prey more accessible in short swards but more abundant in longer swards and therefore the interface of longer and shorter swards, such as around islets, may be valuable foraging areas (Douglas et al., 2009).

Field Code Changed 


\section{Acknowledgements}

This work was part of the Ag-Biota Project, funded by the Environmental Protection Agency, Ireland (2001-CD/B1-M1) through the ERTDI Programme under the National Development Plan (2000- 2006). Tim Carnus, Rónan Gleeson, Julie Melling and Yasmine Lovic gave excellent assistance in the collection and sorting of samples. We thank Michael Drennan and Teagasc for permitting access to their suckler beef grassland experiments at Teagasc Grange, and Anne Kinsella for her assistance in the random selection of commercial farms from the National Farm Survey (NFS) database for the purpose of the 26-site farm survey. We are also very grateful to all the farmers who allowed us access to their farms and for their cooperation throughout our work. 


\section{References}

Altieri, M.A. (1999) The ecological role of biodiversity in agroecosystems. Agriculture, Ecosystems and Environment, 74, 19-31.

Formatted: Font: Italic

Formatted: Indent: Left: 0 pt, First line: 0 pt

Formatted: Font: Bold

Anderson, A., Helden, A., Carnus, T., Gleeson, R., Sheridan, H., McMahon, B., Melling, J.,

Lovic, Y., \& Purvis, G. (2008) Arthropod biodiversity of agricultural grassland in south and east Ireland: introduction, sampling sites and Araneae. Bulletin of the Irish Biogeographical Society, 32, 142-159.

Andrzejewska, L. (1965) Stratification and its dynamics in meadow communities of Auchenorrhyncha (Homoptera). Ekologia Polska - Seria A, 13, 685-715.

Formatted: Font: Italic

Formatted: Font: Bold

Andrzejewska, L. (1976) The influence of mineral fertilization on the meadow phytophagous fauna. Polish Ecological Studies, 2, 93-109.

Arnold, A.J. (1994) Insect suction sampling without nets, bags or filters. Crop Protection, 13,

Formatted: Font: Italic Formatted: Font: Bold Formatted: Font: Italic Formatted: Font: Bold $\underline{73-76 .}$

Baines, M., Hambler, C., Johnson, P.J., Macdonald, D.W., \& Smith, H. (1998) The effects of arable field margin management on the abundance and species richness of Araneae (spiders).

Ecography, 21, 74-86.

Formatted: Font: Italic

Formatted: Font: Bold

Barry, P., Culleton, N., \& Fox, R. (2002). Management systems for organic spring milk

production. In Principles of Successful Organic Farming. (eds N. Culleton, P. Barry, R. Fox,

Formatted: Font: Italic

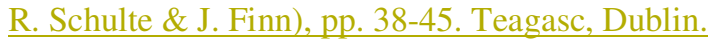

Bayram, A. \& Luff, M.L. (1993) Winter Abundance and Diversity of Lycosids (Lycosidae, 
Bell, J.R., Wheater, C.P., \& Cullen, W.R. (2001) The implications of grassland and heathland management for the conservation of spider communities: a review. Journal of Zoology, 255,

Formatted: Font: Italic

Formatted: Font: Bold 377-387.

Benton, T.G., Vickery, J.A., \& Wilson, J.D. (2003) Farmland biodiversity: is habitat

heterogeneity the key? Trends in Ecology and Evolution, 18, 182-188.

Boom, C.J. \& Sheath, G.W. (2008) Migration of gastrointestinal nematode larvae from cattle

faecal pats onto grazable herbage. Veterinary Parasitology, 157, 260-266.

Bosker, T., Hoekstra, N.J., \& Lantinga, E.A. (2002) The influence of feeding strategy on

growth and rejection of herbage around dung pats and their decomposition. Journal of

Agricultural Science, 139, 213-221.

Bossenbroek, P., Kessler, A., Liem, A.S.N., \& Vlijm, L. (1977a) Experimental-Analysis of

Significance of Tuft-Structures as a Shelter for Invertebrate Fauna, with Respect to Wind-

Velocity and Temperature. Journal of Zoology, 182, 7-16.

Bossenbroek, P., Kessler, A., Liem, A.S.N., \& Vlijm, L. (1977b) Significance of Plant

Growth-Forms as Shelter for Terrestrial Animals. Journal of Zoology, 182, 1-6.

Boswell, C.C. (1971) Fouling of pastures by grazing cattle. Journal of the British Grassland

Society, 26, 194.

Brook, A.J., Woodcock, B.A., Sinka, M., \& Vanbergen, A.J. (2008) Experimental

verification of suction sampler capture efficiency in grasslands of differing vegetation height

and structure. Journal of Applied Ecology, 45, 1357-1363.

Formatted: Font: Italic

Formatted: Font: Bold

Castle, M.E. \& MacDaid, E. (1972) The decomposition of cattle dung and its effect on

Formatted: Font: Italic

Formatted: Font: Bold 
Cattin, M.F., Blandenier, G., Banasek-Richter, C., \& Bersier, L.F. (2003) The impact of mowing as a management strategy for wet meadows on spider (Araneae) communities.

Biological Conservation, 113, 179-188.

Chesson, P. (2000) Mechanisms of maintenance of species diversity. Annual Review of

Ecology and Systematics, 31, 343-366.

Crawley, M.J. (2007) The R Book. John Wiley \& Sons, Ltd, Chichester.

Curry, J.P. (1987a) The invertebrate fauna of grassland and its influence on productivity. I.

The composition of the fauna. Grass and Forage Science, 42, 103-120.

Formatted: Font: Italic

Formatted: Font: Bold

Curry, J.P. (1987b) The invertebrate fauna of grassland and its influence on productivity. II.

Factors affecting the abundance and composiiton of the fauna. Grass and Forage Science,42,

Formatted: Font: Italic

Formatted: Font: Bold $197-212$.

D'Hulster, M. \& Desender, K. (1982) Ecological and faunal studies on Coleoptera in

agricultural land III. Seasonal abundance and hibernation of Staphylinidae in the grassy edge

of a pasture. Pedobiologia, 23, 403-414.

Formatted: Font: Italic

Formatted: Font: Bold

D'Hulster, M. \& Desender, K. (1984) Ecological and faunal studies of Coleoptera in

agricultural land IV. Hibernation of Staphylinidae in agro-ecosystems. Pedobiologia, 26, 65-

Formatted: Font: Italic

Formatted: Font: Bold

73.

Davidson, A.D. \& Lightfoot, D.C. (2006) Keystone rodent interactions: prairie dogs and

kangaroo rats structure the biotic composition of a desertified grassland. Ecography, 29, 755-

Formatted: Font: Italic

Formatted: Font: Bold $\underline{765 .}$

De Keer, R., Alderweireldt, M., Decleer, K., Segers, H., Desender, K., \& Maelfait, J.-P. (1989) Horizontal distribution of the spider fauna of intensively grazed pastures under the 
De Keer, R., Desender, K., D'Hulster, M., \& Maelfait, J.-P. (1986) The importance of edges for the spider and beetle fauna of a pasture. Annales de la Société Royale Zoologique de Belgique, 116, 92-93.

Dennis, P., Thomas, M.B., \& Sotherton, N.W. (1994) Structural features of field boundaries which influence the overwintering densities of beneficial arthropod predators. Journal of Applied Ecology, 31, 361-370.

Dennis, P., Young, M.R., \& Gordon, I.J. (1998) Distribution and abundance of small insects and arachnids in relation to structural heterogeneity of grazed, indigenous grasslands.

Ecological Entomology, 23, 253-264.

Denno, R.F. \& Roderick, G.K. (1990) Population biology of planthoppers. Annual Review of Entomology, 35, 489-520.

Desender, K. (1982) Ecological and faunal studies on Coleoptera in agricultural land II.

Hibernation of Carabidae in agro-ecosystems. Pedobiologia, 23, 295-303.

Desender, K., Alderweireldt, M., \& Pollet, M. (1989) Field edges and their importance for polyphagous predatory arthropods. Mededelingen van de Faculteit Landbouw,

Rijksuniversiteit Gent, 54, 823-833.

Donald, P.F. \& Evans, A.D. (2006) Habitat connectivity and matrix restoration: the wider implications of agri-environment schemes. Journal of Applied Ecology, 43, 209-218. Douglas, D.J.T., Vickery, J.A., \& Benton, T.G. (2009) Improving the value of field margins as foraging habitat for farmland birds. Journal of Applied Ecology, 46, 353-362. Emerson, H.J. \& Gillmor, D.A. (1999) The Rural Environment Protection Scheme of the Republic of Ireland. Land Use Policy, 16, 235-245. Fossitt, J.A. (2000) A Guide to Habitats in Ireland. Heritage Council, Kilkenny.
Formatted: Font: Italic

Formatted: Font: Bold

Formatted: Font: Italic

Formatted: Font: Bold

Formatted: Font: Italic

Formatted: Font: Bold

Formatted: Font: Italic

Formatted: Font: Bold

Formatted: Font: Italic

Formatted: Font: Bold

Formatted: Font: Italic

Formatted: Font: Bold

Formatted: Font: Italic

Formatted: Font: Bold

Formatted: Font: Italic

Formatted: Font: Bold

Formatted: Font: Italic

Formatted: Font: Bold

Formatted: Font: Italic 
Gibb, M.J., Huckle, C.A., Nuthall, R., \& Rook, A.J. (1997) Effect of sward surface height on intake and grazing behaviour by lactating Holstein Friesian cows. Grass and Forage Science, 52, 309-321.

Greenhalgh, J.F.D. \& Reid, G.W. (1968) The effects of grazing intensity on herbage

consumption and animal production. III. Dairy cows grazed at two intensities on clean or contaminated pasture. Journal of Agricultural Science, 71, 223-228.

Harwood, J.D., Sunderland, K.D., \& Symondson, W.O.C. (2003) Web-location by linyphiid spiders: prey-specific aggregation and foraging strategies. Journal of Animal Ecology, 72,

Formatted: Font: Italic

Formatted: Font: Bold

Formatted: Font: Italic

Formatted: Font: Bold

Formatted: Font: Italic

Formatted: Font: Bold 745-756.

Haynes, R.J. \& Williams, P.H. (1993) Nutrient Cycling and Soil Fertility in the Grazed

Pasture Ecosystem. Advances in Agronomy, 49, 119-199.

Formatted: Font: Italic

Formatted: Font: Bold

Helden, A.J. \& Leather, S.R. (2004) Biodiversity on urban roundabouts - Hemiptera,

management and the species-area relationship. Basic and Applied Ecology, 5, 367-377.

Formatted: Font: Italic

Formatted: Font: Bold

Humbert, J.Y., Ghazoul, J., \& Walter, T. (2009) Meadow harvesting techniques and their

impacts on field fauna. Agriculture Ecosystems \& Environment, 130, 1-8.

Formatted: Font: Italic

$\underline{\text { Knapp, A.K., Blair, J.M., Briggs, J.M., Collins, S.L., Hartnett, D.C., Johnson, L.C., \& }}$

Towne, E.G. (1999) The keystone role of bison in north American tallgrass prairie - Bison

increase habitat heterogeneity and alter a broad array of plant, community, and ecosystem

processes. Bioscience, 49, 39-50.

Formatted: Font: Italic

Formatted: Font: Bold

$\underline{\text { Krebs, J.R., Wilson, J.D., Bradbury, R.B., \& Siriwardena, G.M. (1999) The second Silent }}$

Spring? Nature, 400, 611-612.

Formatted: Font: Italic

Formatted: Font: Bold

Lantinga, E.A., Kuening, J.A., Groenwold, J., \& Deenen, P.J.A.G. (1987). Distribution of

excreted nitrogen by grazing cattle and its effects on sward quality, herbage production and 
utilization. In Animal Manure on Grassland and Fodder Crops (ed H.G. Meer vd), pp. 103117. Martinus Nijhoff Publishers, Dordrecht.

Luff, M.L. (1965a) A list of Coleoptera occurring in grass tussocks. Entomologist's Monthly Magazine, 101, 240-245.

Luff, M.L. (1965b) The morphology and microclimate of Dactylis glomerata tussocks. Journal of Ecology, 53, 771-787.

Luff, M.L. (1966) The abundance and diversity of the beetle fauna of grass tussocks. Journal of Animal Ecology, 35, 189-208.

MacDiarmid, B.N. \& Watkin, B.R. (1971) The cattle dung patch. 1. Effect of dung patches on yield and botanical composition of surrounding and underlying pasture. Journal of the British Grassland Society, 26, 239-245.

MacDiarmid, B.N. \& Watkin, B.R. (1972) The cattle dung patch. 3. Distribution and rate of decay of dung patches and their influence on grazing bahaviour. Journal of the British Grassland Society, 27, 48-54.

MacLusky, D.S. (1960) Some estimates of the area of pasture fouled by the excreta of dairy cows. Journal of the British Grassland Society, 15, 181-188.

Maelfait, J.-P. \& De Keer, R. (1990) The border zone of an intensively grazed pasture as a corridor for spiders Araneae. Biological Conservation, 54, 223-238.

Marsh, R. \& Campling, R.C. (1970) Fouling of pastures by dung. Herbage Abstracts, 40, $\underline{123-130 .}$

Marten, G.C. \& Donker, J.D. (1964a) Selective grazing induced by animal excreta. I. Evidence of occurrence and superficial remedy. Journal of Dairy Science, 47, 773-776. Marten, G.C. \& Donker, J.D. (1964b) Selective grazing induced by animal excreta. II. Investigation of a causal theory. Journal of Dairy Science, 47, 871-874.
Formatted: Font: Italic

Formatted: Font: Italic

Formatted: Font: Bold

Formatted: Font: Italic

Formatted: Font: Italic

Formatted: Font: Bold

Formatted: Font: Italic

Formatted: Font: Bold

Formatted: Font: Italic

Formatted: Font: Bold

Formatted: Font: Italic

Formatted: Font: Bold

Formatted: Font: Italic

Formatted: Font: Bold

Formatted: Font: Italic

Formatted: Font: Bold

Formatted: Font: Italic

Formatted: Font: Bold

Formatted: Font: Italic

Formatted: Font: Bold

Formatted: Font: Italic

Formatted: Font: Bold 
McNaughton, S.J. (1984) Grazing Lawns - Animals in Herds, Plant Form, and Coevolution.

American Naturalist, 124, 863-886.

Formatted: Font: Italic

Formatted: Font: Bold

Mikola, J., Setala, H., Virkajarvi, P., Saarijarvi, K., Ilmarinen, K., Voigt, W., \& Vestberg, M.

(2009) Defoliation and patchy nutrient return drive grazing effects on plant and soil

properties in a dairy cow pasture. Ecological Monographs, 79, 221-244.

Formatted: Font: Italic

Formatted: Font: Bold

Morris, M.G. (2000) The effects of structure and its dynamics on the ecology and

conservation of arthropods in British grasslands. Biological Conservation, 95, 129-142.

Formatted: Font: Italic

Formatted: Font: Bold

Morris, M.G. \& Lakhani, K.H. (1979) Responses of grassland invertebrates to management

by cutting. I Species diversity of Hemiptera. Journal of Applied Ecology, 16, 77-98.

Formatted: Font: Italic

Formatted: Font: Bold

Morris, M.G. \& Rispin, W.E. (1987) Abundance and diversity of the coleopterous fauna of a

calcareous grassland under different cutting regimes. Journal of Applied Ecology, 24, 451-

Formatted: Font: Italic

Formatted: Font: Bold 465.

Norman, M.J.T. \& Green, J.O. (1958) The local influence of cattle dung and urine upon the yield and botanical composition of permanent pasture. Journal of the British Grassland

Society, $13,39-45$.

Olechowicz, E. (1976) The effect of mineral fertilization on insect community of the herbage

in a meadow. Polish Ecological Studies, 2, 129-136.

Formatted: Font: Italic

Formatted: Font: Bold

Parish, R. \& Turkington, R. (1990) The colonization of dung pats and molehills in permanent

pastures. Canadian Journal of Botany, 68, 1706-1711.

Formatted: Font: Italic

Formatted: Font: Bold

Pearce, E.J. (1948) The invertebrate fauna of grass-tussocks: a suggested line for ecological

study. Entomologist's Monthly Magazine, 84, 169-174.

Formatted: Font: Italic

Formatted: Font: Bold

$\underline{\text { Pinheiro, J., Bates, D., DebRoy, S., \& Sarkar, D. (2009) nlme: Linear and Nonlinear Mixed }}$

Effects Models. R package version 3.1-96. 
Plice, M.J. (1951) Sugar versus the intuitive choice of foods by livestock. Agronomy Journal, $43,341-342$.

Purvis, G., Anderson, A., Baars, J.-R., Bolger, T., Breen, J., Connolly, J., Curry, J., Doherty, $\underline{\text { P., Doyle, M., Finn, J., Geijzendorffer, I., Helden, A., Kelly-Quinn, M., Kennedy, T., }}$ Kirwan, L., McDonald, J., McMahon, B., Miksche, D., Santorum, V., Schmidt, O., Sheehan, C., \& Sheridan, H. (2009) Ag-Biota: Monitoring, Functional Significance and Management for the Maintenance and Economic Utilisation of Biodiversity in the Intensively Farmed Landscape. Environmental Protection Agency.

<http://erc.epa.ie/safer/iso19115/displayISO19115.jsp?isoID=108> 24th May 2010. Johnstown Castle, Ireland.

R Development Core Team (2009) R: A language and environment for statistical computing. $\underline{\text { R Foundation for Statistical Computing, Vienna, Austria. ISBN 3-900051-07-0, URL }}$ http://www.R-project.org.

Robinson, R.A. \& Sutherland, W.J. (2002) Post-war changes in arable farming and biodiversity in Great Britain. Journal of Applied Ecology, 39, 157-176. $\underline{\text { Rook, A.J. \& Tallowin, J.R.B. (2003) Grazing and pasture management for biodiversity }}$ benefit. Animal Research, 52, 181-189. Schulte, R.P.O., Lantinga, E.A., \& Struik, P.C. (2003) Analysis of the production stability of mixed grasslands I: A conceptual framework for the qualification of production stability in grassland ecosystems. Ecological Modelling, 159, 43-69.

Schwinning, S. \& Parsons, A.J. (1996) Analysis of the coexistence mechanisms for grasses and legumes in grazing systems. Journal of Ecology, 84, 799-813.

Skidmore, P. (1991) Insects of the British Cow Dung Community Field Studies Council.
Formatted: Font: Italic

Formatted: Font: Bold

Formatted: Font: Italic

Formatted: Font: Italic

Formatted: Font: Bold

Formatted: Font: Italic

Formatted: Font: Bold

Formatted: Font: Italic

Formatted: Font: Bold

Formatted: Font: Italic

Formatted: Font: Bold

Formatted: Font: Italic 
Tayler, J.C. \& Large, R.V. (1955) The comparative output of two seeds mixtures. Journal of the British Grassland Society, 10, 341-351.

Tayler, J.C. \& Rudman, J.E. (1966) The distribution of herbage at different heights in 'grazed' and 'dung patch' areas of a sward under two methods of grazing management. Journal of Agricultural Science, 66, 29-39.

The Heritage Council (2005) Draft Habitat Survey Guidelines. A Standard Methology for Habitat Survey and Mapping in Ireland. The Heritage Council. <http://www.heritagecouncil.ie/fileadmin/user_upload/Publications/Wildlife/HabitatSurveyG uidelines_2_Draft_April_2005.doc>24th May 2010.

Vickery, J.A., Tallowin, J.R., Feber, R.E., Asteraki, E.J., Atkinson, P.W., Fuller, R.J., \& Brown, V.K. (2001) The management of lowland neutral grasslands in Britain: effects of agricultural practices on birds and their food resources. Journal of Applied Ecology, 38, 647-

Formatted: Font: Italic Formatted: Font: Bold $\underline{664 .}$

Wallis De Vries, M.F., Parkinson, A.E., Dulphy, J.P., Sayer, M., \& Diana, E. (2007) Effects of livestock breed and grazing intensity on biodiversity and production in grazing systems. 4. Effects on animal diversity. Grass and Forage Science, 62, 185-197.

Formatted: Font: Italic Formatted: Font: Bold

Weeda, W.C. (1967) The effect of cattle dung patches on pasture growth, botanical composition, and pasture utilisation. New Zealand Journal of Agricultural Research, 10, 150-

Formatted: Font: Italic Formatted: Font: Bold $\underline{159}$.

Woodcock, B.A., Potts, S.G., Tscheulin, T., Pilgrim, E., Ramsey, A.J., Harrison-Cripps, J., Brown, V.K., \& Tallowin, J.R. (2009) Responses of invertebrate trophic level, feeding guild and body size to the management of improved grassland field margins. Journal of Applied Ecology, 46, 920-929.

Formatted: Font: Italic

Formatted: Font: Bold 
Woodcock, B.A., Potts, S.G., Westbury, D.B., Ramsay, A.J., Lambert, M., Harris, S.J., \&

\section{Brown, V.K. (2007) The importance of sward architectural complexity in structuring}

predatory and phytophagous invertebrate assemblages. Ecological Entomology, 32, 302-311.

Table 1. Summary of linear mixed model (lme) comparisons of the abundance of arthropods in islets and non-islets, from the 26 sites of the multi-farm survey. Parameter estimates are given in $\log (\ln )$ values. Degrees of freedom for the estimates of the slope parameter estimates
Formatted: Font: Italic

Formatted: Font: Bold

Deleted: Altieri, M.A. (1999)

The ecological role of biodiversity in agroecosystems. Agriculture,

Ecosystems and Environment, 74, 19-31.II

Anderson, A., Helden, A., Carnus, T., Gleeson, R., Sheridan, H.,

McMahon, B., Melling, J., Lovic, Y., \& Purvis, G. (2008) Arthropod

biodiversity of agricultural grassland in south and east Ireland:

introduction, sampling sites and

Araneae. Bulletin of the Irish

Biogeographical Society, 32, 142159.II

Andrzejewska, L. (1965)

Stratification and its dynamics in

meadow communities of

Auchenorrhyncha (Homoptera).

Ekologia Polska - Seria A, 13, 685-

715.II

Andrzejewska, L. (1976) The

influence of mineral fertilization on the meadow phytophagous fauna.

Polish Ecological Studies, 2, 93-109.9

Arnold, A.J. (1994) Insect suction sampling without nets, bags or

filters. Crop Protection, 13, 73-76.|I

Baines, M., Hambler, C., Johnson, P.J., Macdonald, D.W., \& Smith, H. (1998) The effects of arable field margin management on the abundance and species richness of Araneae (spiders). Ecography, 21, 74-86.II

Barry, P., Culleton, N., \& Fox, R. (2002). Management systems for organic spring milk production. In Principles of Successful Organic Farming. (eds N. Culleton, P. Barry,

R. Fox, R. Schulte \& J. Finn), pp. 38-45. Teagasc, Dublin.II Bayram, A. \& Luff, M.L. (1993) Winter Abundance and Diversity of Lycosids (Lycosidae, Araneae) and Other Spiders in Grass Tussocks in a Field Margin. Pedobiologia, 37, 357364.II

Bell, J.R., Wheater, C.P., \& Cullen, W.R. (2001) The implications of grassland and heathland management for the conservation of spider communities: a review. Journal of Zoology, 255, 377-387.II

Benton, T.G., Vickery, J.A., \& Wilson, J.D. (2003) Farmland biodiversity: is habitat heterogeneity the key? Trends in Ecology and Evolution, 18, 182-188.II Boom, C.J. \& Sheath, G.W. (2 ... 1$]$ 
were 23; so for a given slope parameter the equivalent numerator and denominator d.f. (e.g. sward height) would be 1 and 23 degrees of freedom. Significance is indicated as: *** $\mathrm{p}<0.001, * * \mathrm{p}<0.01, * \mathrm{p}<0.05$.

\begin{tabular}{|l|l|l|l|l|}
\hline $\begin{array}{l}\text { Arthropod } \\
\text { group }\end{array}$ & \multicolumn{4}{|c|}{ Parameter estimates } \\
\hline & $\begin{array}{l}\text { intercept (non- } \\
\text { islets) }\end{array}$ & islets & sward height & $\begin{array}{l}\text { islet:sward } \\
\text { height } \\
\text { interaction }\end{array}$ \\
\hline Araneae & $2.539 * * *$ & $2.739 * * *$ & $0.176^{*}$ & $-0.213^{* *}$ \\
\hline Coleoptera & $1.986^{* * *}$ & $3.092^{* * *}$ & $0.203 * * *$ & $-0.257^{* * *}$ \\
\hline Diptera & $3.336^{* * *}$ & $2.844^{* *}$ & $0.195^{*}$ & $-0.214^{*}$ \\
\hline Hemiptera & $2.568^{* * *}$ & $2.037^{* * *}$ & $0.229^{* *}$ & $-0.184^{* *}$ \\
\hline Hymenoptera & $2.645^{* * *}$ & $2.210^{* * *}$ & $0.160^{* *}$ & $-0.176^{* * *}$ \\
\hline
\end{tabular}

Table 2. Minimal adequate models from generalised linear modelling (glm) of the proportion of arthropods (abundance in islets/total abundance) collected in islets at the 26 multi-farm survey sites. Parameter estimates given in terms of logits. The logit estimates (x) can be 
converted to proportions as follows: $\exp (\mathrm{x}) /(1+(\exp (\mathrm{x}))$. Degrees of freedom (d.f.) are given; for a given slope parameter (e.g. Araneae sward ht) the equivalent numerator and denominator d.f. would be 1 and 23 degrees of freedom. Significance is indicated as: *** $\mathrm{p}<0.001, * * \mathrm{p}<0.01, * \mathrm{p}<0.05$.

\begin{tabular}{|l|l|l|l|l|}
\hline Arthropod & Model & Parameter estimates & d.f. & Deviance \\
& & variables $)$ & & $(\%)$ \\
& & & & \\
\hline Araneae & $\sim$ sward ht + prop & $2.665^{* * *}-0.291^{* * *}+2.868^{* * *}$ & 23 & 50.3 \\
\hline Coleoptera & $\sim$ habitat div + sward ht & $2.223^{* * *}+0.376^{*}-0.195^{* * *}$ & 23 & 67.0 \\
\hline Diptera & $\sim$ date & $9.969^{* *}-0.043^{*}$ & 24 & 23.6 \\
\hline Hemiptera & $\sim$ system + sward ht + & $2.845^{* * *}+0.445^{*}-0.335^{* * *}+$ & 22 & 63.6 \\
& prop & $2.925^{* *}$ & & \\
\hline Hymenoptera & $\sim$ non-crop + habitat div & $2.466^{* * *}-5.810^{*}+0.434^{* *}-$ & 20 & 76.7 \\
\hline & + sward ht + prop + & $0.327^{* * *}+1.915^{* *}+0.933^{* *}$ & & \\
\hline
\end{tabular}

Table 3. Minimal adequate models from generalised linear mixed modelling (lmer) of the proportion of arthropods collected in islets from the pasture management experiment (Teagasc Grange). Proportion of arthropods in islets (abundance in islets/total abundance) 
with parameter estimates given in terms of logits. The logit estimates $(\mathrm{x})$ can be converted to proportions as follows: $\exp (\mathrm{x}) /(1+(\exp (\mathrm{x}))$. Model structure was such that it was equivalent to having numerator and denominator degrees of freedom for parameter estimates of 1 and 4 . $((2$ treatments $)-1=1 ;(3$ plots/treatment $)-1=2 \times 2$ treatments $)$.

\begin{tabular}{|c|c|c|c|}
\hline Arthropod group & Model & $\begin{array}{l}\text { Parameter estimates } \\
\text { (intercept } \pm \text { explanatory } \\
\text { variables) }\end{array}$ & $\begin{array}{l}\text { Deviance } \\
\text { explained } \\
(\%)\end{array}$ \\
\hline Araneae & sward ht & $1.000 * *-0.032 *$ & 1.9 \\
\hline Coleoptera & $\begin{array}{l}\text { treatment }+ \text { sward ht }+ \\
\text { treatment:sward ht }\end{array}$ & $\begin{array}{l}1.595 * * *+1.177^{*}- \\
0.056-0.116^{* *}\end{array}$ & 38.1 \\
\hline Hemiptera (all & treatment + sward ht + & $1.091^{* * *}+1.256^{* * *}-$ & 20.1 \\
\hline individuals) & treatment:sward ht & $0.037^{*}-0.083^{* *}$ & \\
\hline $\begin{array}{l}\text { Hemiptera } \\
\text { (minus aphid } \\
\text { juveniles) }\end{array}$ & sward ht & $1.706 * * *-0.095 * * *$ & 56.0 \\
\hline Hymenoptera & sward ht & $1.362 * * *-0.056 * * *$ & 9.8 \\
\hline
\end{tabular}

Figure legends

Figure 1. A well defined islet in a cattle-grazed pasture 
Figure 2. Boxplots showing the median proportion of the total overall populations from the multi-farm survey pastures of Araneae (aran), Coleoptera (col), Diptera (dipt), Hemiptera (hem) and Hymenoptera (hym) estimated to be found in islets. Proportion data were estimated from the numbers collected and the relative area of islets. Also shown is the proportion of field area covered by islets (islets) from the same 26 sites. Boxplots show the median values as the dark horizontal lines and figures; $25^{\text {th }}$ and $75^{\text {th }}$ percentiles as the top and bottom of the boxes. The dashed lines show either 1.5 times the interquartile range together with outliers as small circles, or if there are no outliers, the maximum and minimum values,

Deleted: ; and

Deleted: range is represented by the

Deleted: dashed lines

Figure 3. Change with sward height, in the proportion of all individuals of Araneae,

Coleoptera, Hemiptera and Hymenoptera collected in islets at the multi-farm survey sites. For the Hemiptera the dashed line indicates non-dairy and the solid line dairy sites.

Appendix Figure 1. Location of the 26 multi-farm survey sites (closed circles) and the pasture management experiment at Teagasc Grange (open triangle). 
Figure 1.

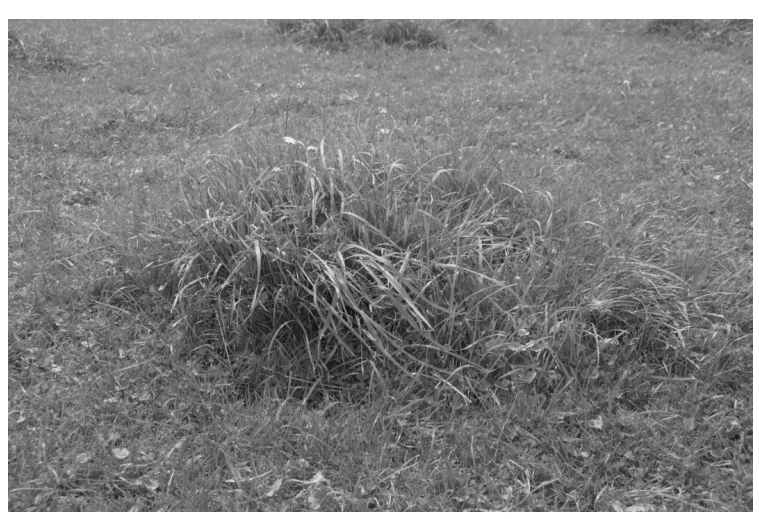

Figure 2. 


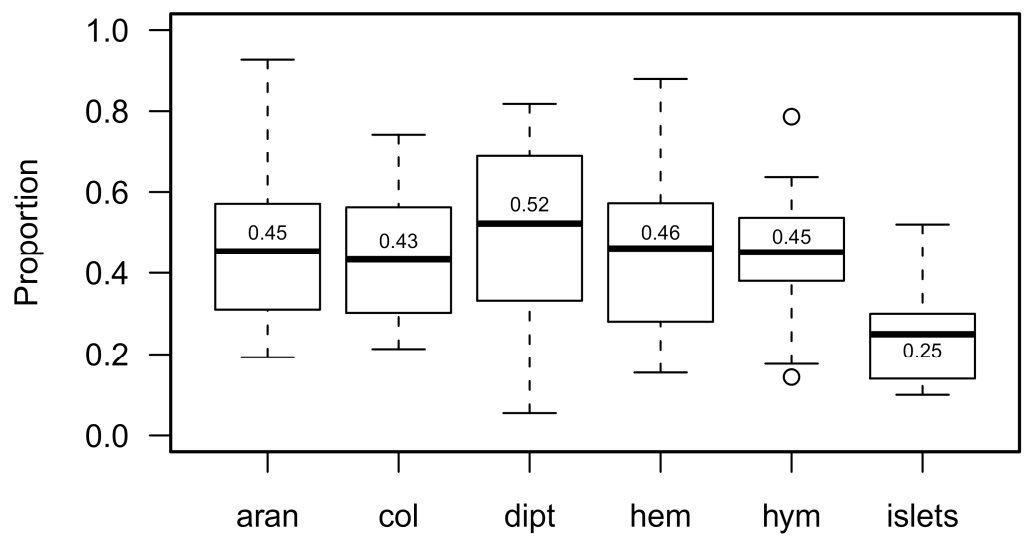

Figure 3, 

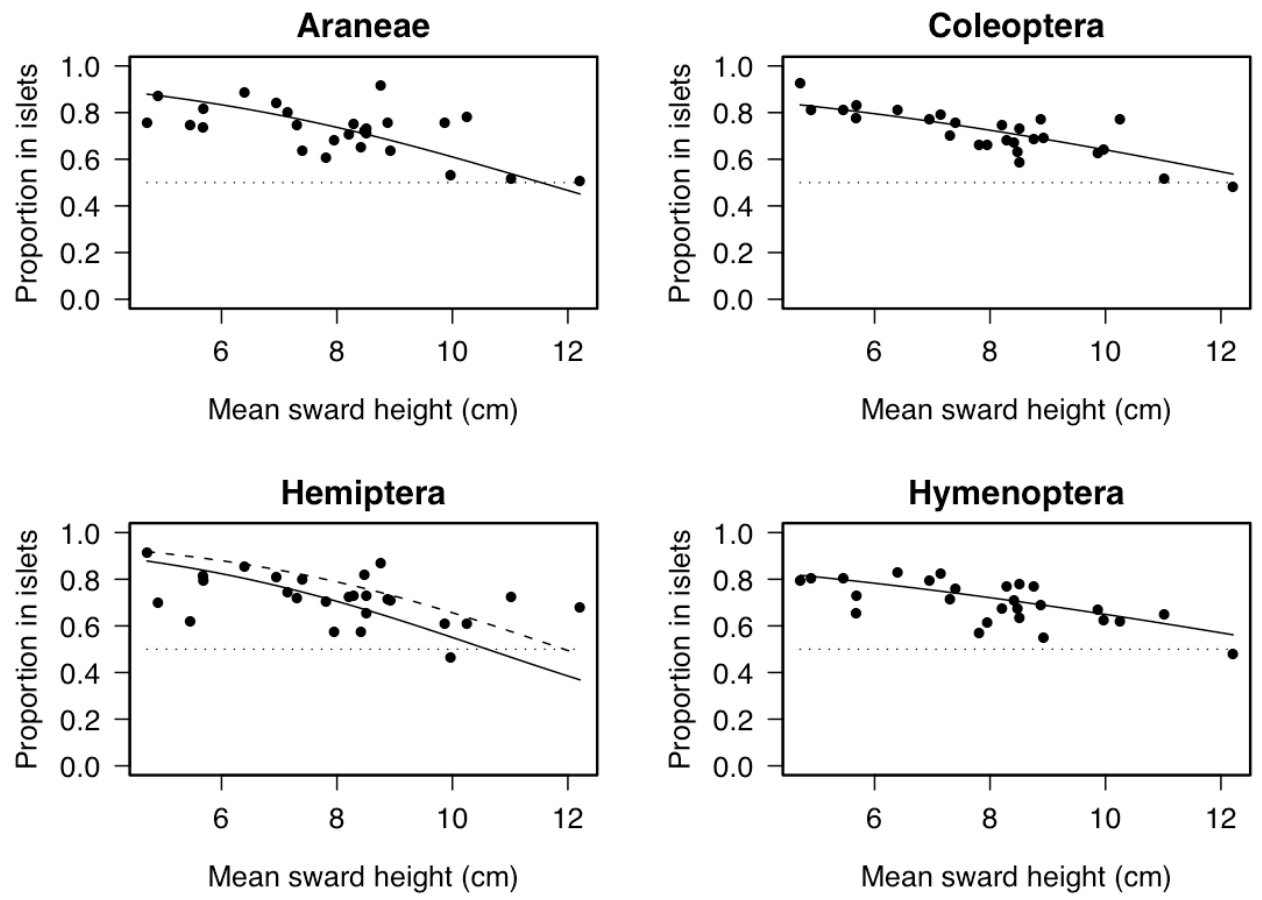
Appendix Table 1. Mean sward height in eight of the Teagasc Grange paddocks on ten dates between May and September 2003. Values over 12_cm are shown in bold.

\begin{tabular}{|c|c|c|c|c|c|c|c|c|c|c|}
\hline \multirow[t]{3}{*}{ Paddock name } & \multicolumn{10}{|c|}{ Date } \\
\hline & 7 & 27 & 11 & 17 & 3 & 15 & 30 & 14 & 26 & 9 \\
\hline & May & May & June & June & July & July & July & Aug & Aug & Sept \\
\hline Conventional M1 & 6.9 & 5.0 & 8.5 & 8.1 & 6.1 & 10.4 & 5.9 & 9.4 & 14.0 & 14.7 \\
\hline Conventional M2 & 7.2 & 4.9 & 9.0 & 10.5 & 7.5 & 8.7 & 5.6 & 10.0 & 13.3 & 14.7 \\
\hline REPS M1 & 8.6 & 4.2 & 9.0 & 9.0 & 7.4 & 7.3 & 13.0 & 6.3 & 9.9 & 11.2 \\
\hline REPS M2 & 7.2 & 6.1 & 8.1 & 10.2 & 6.9 & 11.0 & 14.0 & 7.3 & 10.3 & 11.2 \\
\hline Conventional F1 & 5.3 & 7.8 & 6.5 & 5.8 & 7.0 & 5.1 & 7.4 & 12.7 & 6.6 & 8.8 \\
\hline Conventional F2 & 5.2 & 6.0 & 5.4 & 3.7 & 5.7 & 9.3 & 6.4 & 12.2 & 6.6 & 7.0 \\
\hline REPS C1 & 5.4 & 6.7 & 4.9 & 5.0 & 8.7 & 9.8 & 5.1 & 8.9 & 5.0 & 6.7 \\
\hline REPS C2 & 5.9 & 6.8 & 6.4 & 5.9 & 6.7 & 9.2 & 5.5 & 9.2 & 5.6 & 5.4 \\
\hline
\end{tabular}


Appendix Figure 1.

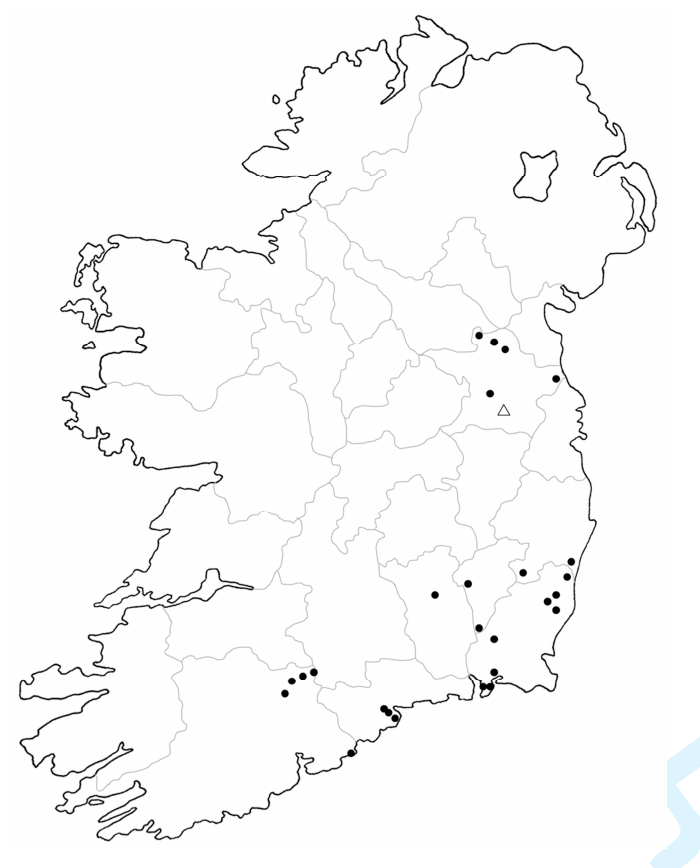


Page 31: [1] Deleted

Altieri, M.A. (1999) The ecological role of biodiversity in agroecosystems. Agriculture, Ecosystems and Environment, 74, 19-31.

Anderson, A., Helden, A., Carnus, T., Gleeson, R., Sheridan, H., McMahon, B., Melling, J., Lovic, Y., \& Purvis, G. (2008) Arthropod biodiversity of agricultural grassland in south and east Ireland: introduction, sampling sites and Araneae. Bulletin of the Irish Biogeographical Society, 32, 142-159.

Andrzejewska, L. (1965) Stratification and its dynamics in meadow communities of Auchenorrhyncha (Homoptera). Ekologia Polska - Seria A, 13, 685-715.

Andrzejewska, L. (1976) The influence of mineral fertilization on the meadow phytophagous fauna. Polish Ecological Studies, 2, 93-109.

Arnold, A.J. (1994) Insect suction sampling without nets, bags or filters. Crop Protection, 13, 73-76.

Baines, M., Hambler, C., Johnson, P.J., Macdonald, D.W., \& Smith, H. (1998) The effects of arable field margin management on the abundance and species richness of Araneae (spiders). Ecography, 21, 74-86.

Barry, P., Culleton, N., \& Fox, R. (2002). Management systems for organic spring milk production. In Principles of Successful Organic Farming. (eds N. Culleton, P. Barry, R. Fox, R. Schulte \& J. Finn), pp. 38-45. Teagasc, Dublin.

Bayram, A. \& Luff, M.L. (1993) Winter Abundance and Diversity of Lycosids (Lycosidae, Araneae) and Other Spiders in Grass Tussocks in a Field Margin. Pedobiologia, 37, 357-364. 
Bell, J.R., Wheater, C.P., \& Cullen, W.R. (2001) The implications of grassland and heathland management for the conservation of spider communities: a review. Journal of Zoology, 255, 377-387.

Benton, T.G., Vickery, J.A., \& Wilson, J.D. (2003) Farmland biodiversity: is habitat heterogeneity the key? Trends in Ecology and Evolution, 18, 182-188.

Boom, C.J. \& Sheath, G.W. (2008) Migration of gastrointestinal nematode larvae from cattle faecal pats onto grazable herbage. Veterinary Parasitology, 157, 260-266.

Bosker, T., Hoekstra, N.J., \& Lantinga, E.A. (2002) The influence of feeding strategy on growth and rejection of herbage around dung pats and their decomposition. Journal of Agricultural Science, 139, 213-221.

Bossenbroek, P., Kessler, A., Liem, A.S.N., \& Vlijm, L. (1977a) Experimental-Analysis of Significance of Tuft-Structures as a Shelter for Invertebrate Fauna, with Respect to Wind-Velocity and Temperature. Journal of Zoology, 182, 7-16.

Bossenbroek, P., Kessler, A., Liem, A.S.N., \& Vlijm, L. (1977b) Significance of Plant Growth-Forms as Shelter for Terrestrial Animals. Journal of Zoology, 182, 1-6. Boswell, C.C. (1971) Fouling of pastures by grazing cattle. Journal of the British Grassland Society, 26, 194.

Brook, A.J., Woodcock, B.A., Sinka, M., \& Vanbergen, A.J. (2008) Experimental verification of suction sampler capture efficiency in grasslands of differing vegetation height and structure. Journal of Applied Ecology, 45, 1357-1363.

Castle, M.E. \& MacDaid, E. (1972) The decomposition of cattle dung and its effect on pasture. Journal of the British Grassland Society, 27, 133-137. 
Cattin, M.F., Blandenier, G., Banasek-Richter, C., \& Bersier, L.F. (2003) The impact of mowing as a management strategy for wet meadows on spider (Araneae) communities. Biological Conservation, 113, 179-188.

Chesson, P. (2000) Mechanisms of maintenance of species diversity. Annual Review of Ecology and Systematics, 31, 343-366.

Crawley, M.J. (2007) The R Book. John Wiley \& Sons, Ltd, Chichester.

Curry, J.P. (1987a) The invertebrate fauna of grassland and its influence on productivity. I. The composition of the fauna. Grass and Forage Science, 42, 103-120.

Curry, J.P. (1987b) The invertebrate fauna of grassland and its influence on productivity. II. Factors affecting the abundance and composiiton of the fauna. Grass and Forage Science, 42, 197-212.

D'Hulster, M. \& Desender, K. (1982) Ecological and faunal studies on Coleoptera in agricultural land III. Seasonal abundance and hibernation of Staphylinidae in the grassy edge of a pasture. Pedobiologia, 23, 403-414.

D'Hulster, M. \& Desender, K. (1984) Ecological and faunal studies of Coleoptera in agricultural land IV. Hibernation of Staphylinidae in agro-ecosystems. Pedobiologia, 26, 65-73.

Davidson, A.D. \& Lightfoot, D.C. (2006) Keystone rodent interactions: prairie dogs and kangaroo rats structure the biotic composition of a desertified grassland. Ecography, 29, 755-765.

De Keer, R., Alderweireldt, M., Decleer, K., Segers, H., Desender, K., \& Maelfait, J.-P. (1989) Horizontal distribution of the spider fauna of intensively grazed pastures 
under the influence of diurnal activity and grass height. Journal of Applied Entomology, 107, 455-473.

De Keer, R., Desender, K., D'Hulster, M., \& Maelfait, J.-P. (1986) The importance of edges for the spider and beetle fauna of a pasture. Annales de la Société Royale Zoologique de Belgique, 116, 92-93.

Dennis, P., Thomas, M.B., \& Sotherton, N.W. (1994) Structural features of field boundaries which influence the overwintering densities of beneficial arthropod predators. Journal of Applied Ecology, 31, 361-370.

Dennis, P., Young, M.R., \& Gordon, I.J. (1998) Distribution and abundance of small insects and arachnids in relation to structural heterogeneity of grazed, indigenous grasslands. Ecological Entomology, 23, 253-264.

Denno, R.F. \& Roderick, G.K. (1990) Population biology of planthoppers. Annual Review of Entomology, 35, 489-520.

Desender, K. (1982) Ecological and faunal studies on Coleoptera in agricultural land II. Hibernation of Carabidae in agro-ecosystems. Pedobiologia, 23, 295-303.

Desender, K., Alderweireldt, M., \& Pollet, M. (1989) Field edges and their importance for polyphagous predatory arthropods. Mededelingen van de Faculteit Landbouw, Rijksuniversiteit Gent, 54, 823-833.

Donald, P.F. \& Evans, A.D. (2006) Habitat connectivity and matrix restoration: the wider implications of agri-environment schemes. Journal of Applied Ecology, 43, 209218. 
Douglas, D.J.T., Vickery, J.A., \& Benton, T.G. (2009) Improving the value of field margins as foraging habitat for farmland birds. Journal of Applied Ecology, 46, $353-362$.

Emerson, H.J. \& Gillmor, D.A. (1999) The Rural Environment Protection Scheme of the Republic of Ireland. Land Use Policy, 16, 235-245.

Gibb, M.J., Huckle, C.A., Nuthall, R., \& Rook, A.J. (1997) Effect of sward surface height on intake and grazing behaviour by lactating Holstein Friesian cows. Grass and Forage Science, 52, 309-321.

Greenhalgh, J.F.D. \& Reid, G.W. (1968) The effects of grazing intensity on herbage consumption and animal production. III. Dairy cows grazed at two intensities on clean or contaminated pasture. Journal of Agricultural Science, 71, 223-228.

Harwood, J.D., Sunderland, K.D., \& Symondson, W.O.C. (2003) Web-location by linyphiid spiders: prey-specific aggregation and foraging strategies. Journal of Animal Ecology, 72, 745-756.

Haynes, R.J. \& Williams, P.H. (1993) Nutrient Cycling and Soil Fertility in the Grazed Pasture Ecosystem. Advances in Agronomy, 49, 119-199.

Helden, A.J. \& Leather, S.R. (2004) Biodiversity on urban roundabouts - Hemiptera, management and the species-area relationship. Basic and Applied Ecology, 5, 367-377.

Humbert, J.Y., Ghazoul, J., \& Walter, T. (2009) Meadow harvesting techniques and their impacts on field fauna. Agriculture Ecosystems \& Environment, 130, 1-8.

Knapp, A.K., Blair, J.M., Briggs, J.M., Collins, S.L., Hartnett, D.C., Johnson, L.C., \& Towne, E.G. (1999) The keystone role of bison in north American tallgrass prairie 
- Bison increase habitat heterogeneity and alter a broad array of plant, community, and ecosystem processes. Bioscience, 49, 39-50.

Krebs, J.R., Wilson, J.D., Bradbury, R.B., \& Siriwardena, G.M. (1999) The second Silent Spring? Nature, 400, 611-612.

Lantinga, E.A., Kuening, J.A., Groenwold, J., \& Deenen, P.J.A.G. (1987). Distribution of excreted nitrogen by grazing cattle and its effects on sward quality, herbage production and utilization. . In Animal Manure on Grassland and Fodder Crops (ed H.G. Meer vd), pp. 103-117. Martinus Nijhoff Publishers, Dordrecht.

Luff, M.L. (1965a) A list of Coleoptera occurring in grass tussocks. Entomologist's Monthly Magazine, 101, 240-245.

Luff, M.L. (1965b) The morphology and microclimate of Dactylis glomerata tussocks. Journal of Ecology, 53, 771-787.

Luff, M.L. (1966) The abundance and diversity of the beetle fauna of grass tussocks. Journal of Animal Ecology, 35, 189-208.

MacDiarmid, B.N. \& Watkin, B.R. (1971) The cattle dung patch. 1. Effect of dung patches on yield and botanical composition of surrounding and underlying pasture. Journal of the British Grassland Society, 26, 239-245.

MacDiarmid, B.N. \& Watkin, B.R. (1972) The cattle dung patch. 3. Distribution and rate of decay of dung patches and their influence on grazing bahaviour. Journal of the British Grassland Society, 27, 48-54.

MacLusky, D.S. (1960) Some estimates of the area of pasture fouled by the excreta of dairy cows. Journal of the British Grassland Society, 15, 181-188. 
Maelfait, J.-P. \& De Keer, R. (1990) The border zone of an intensively grazed pasture as a corridor for spiders Araneae. Biological Conservation, 54, 223-238.

Marsh, R. \& Campling, R.C. (1970) Fouling of pastures by dung. Herbage Abstracts, 40, 123-130.

Marten, G.C. \& Donker, J.D. (1964a) Selective grazing induced by animal excreta. I. Evidence of occurrence and superficial remedy. Journal of Dairy Science, 47, 773-776.

Marten, G.C. \& Donker, J.D. (1964b) Selective grazing induced by animal excreta. II. Investigation of a causal theory. Journal of Dairy Science, 47, 871-874.

McNaughton, S.J. (1984) Grazing Lawns - Animals in Herds, Plant Form, and Coevolution. American Naturalist, 124, 863-886.

Mikola, J., Setala, H., Virkajarvi, P., Saarijarvi, K., Ilmarinen, K., Voigt, W., \& Vestberg, M. (2009) Defoliation and patchy nutrient return drive grazing effects on plant and soil properties in a dairy cow pasture. Ecological Monographs, 79, 221-244.

Morris, M.G. (2000) The effects of structure and its dynamics on the ecology and conservation of arthropods in British grasslands. Biological Conservation, 95, $129-142$.

Morris, M.G. \& Lakhani, K.H. (1979) Responses of grassland invertebrates to management by cutting. I Species diversity of Hemiptera. Journal of Applied Ecology, 16, 77-98.

Morris, M.G. \& Rispin, W.E. (1987) Abundance and diversity of the coleopterous fauna of a calcareous grassland under different cutting regimes. Journal of Applied Ecology, 24, 451-465. 
Norman, M.J.T. \& Green, J.O. (1958) The local influence of cattle dung and urine upon the yield and botanical composition of permanent pasture. Journal of the British Grassland Society, 13, 39-45.

Olechowicz, E. (1976) The effect of mineral fertilization on insect community of the herbage in a meadow. Polish Ecological Studies, 2, 129-136.

Parish, R. \& Turkington, R. (1990) The colonization of dung pats and molehills in permanent pastures. Canadian Journal of Botany, 68, 1706-1711.

Pearce, E.J. (1948) The invertebrate fauna of grass-tussocks: a suggested line for ecological study. Entomologist's Monthly Magazine, 84, 169-174.

Pinheiro, J., Bates, D., DebRoy, S., \& Sarkar, D. (2009) nlme: Linear and Nonlinear Mixed Effects Models. R package version 3.1-96.

Plice, M.J. (1951) Sugar versus the intuitive choice of foods by livestock. Agronomy Journal, 43, 341-342.

R Development Core Team (2009) R: A language and environment for statistical computing. R Foundation for Statistical Computing, Vienna, Austria. ISBN 3900051-07-0, URL http://www.R-project.org.

Robinson, R.A. \& Sutherland, W.J. (2002) Post-war changes in arable farming and biodiversity in Great Britain. Journal of Applied Ecology, 39, 157-176.

Rook, A.J. \& Tallowin, J.R.B. (2003) Grazing and pasture management for biodiversity benefit. Animal Research, 52, 181-189.

Schulte, R.P.O., Lantinga, E.A., \& Struik, P.C. (2003) Analysis of the production stability of mixed grasslands I: A conceptual framework for the qualification of production stability in grassland ecosystems. Ecological Modelling, 159, 43-69. 
Schwinning, S. \& Parsons, A.J. (1996) Analysis of the coexistence mechanisms for grasses and legumes in grazing systems. Journal of Ecology, 84, 799-813.

Skidmore, P. (1991) Insects of the British Cow Dung Community Field Studies Council.

Tayler, J.C. \& Large, R.V. (1955) The comparative output of two seeds mixtures. Journal of the British Grassland Society, 10, 341-351.

Tayler, J.C. \& Rudman, J.E. (1966) The distribution of herbage at different heights in 'grazed' and 'dung patch' areas of a sward under two methods of grazing management. Journal of Agricultural Science, 66, 29-39.

Vickery, J.A., Tallowin, J.R., Feber, R.E., Asteraki, E.J., Atkinson, P.W., Fuller, R.J., \& Brown, V.K. (2001) The management of lowland neutral grasslands in Britain: effects of agricultural practices on birds and their food resources. Journal of Applied Ecology, 38, 647-664.

Wallis de Vries, M.F., Parkinson, A.E., Dulphy, J.P., Sayer, M., \& Diana, E. (2007) Effects of livestock breed and grazing intensity on biodiversity and production in grazing systems. 4. Effects on animal diversity. Grass and Forage Science, 62 , 185-197.

Weeda, W.C. (1967) The effect of cattle dung patches on pasture growth, botanical composition, and pasture utilisation. New Zealand Journal of Agricultural Research, 10, 150-159.

Woodcock, B.A., Potts, S.G., Westbury, D.B., Ramsay, A.J., Lambert, M., Harris, S.J., \& Brown, V.K. (2007) The importance of sward architectural complexity in structuring predatory and phytophagous invertebrate assemblages. Ecological Entomology, 32, 302-311. 
1

2

3

4

5

6

7

10

11

12

13

14

15

16

17

18

19

20

21

22

23

24

25

26

27

28

29

30

31

32

33

34

35

36

37

38

39

40

41

42

43

44

45

46

47

48

49

50

51

52

53

54

55

56

57

58

59

60 